\title{
Geografia das Exportações de Frutas no Projeto Jaíba - MG: transportes e interconexões com os mercados globais
}

\author{
Geography of Fruit Exports in the Jaíba - MG: transport and interconnections with global \\ markets
}

\author{
Igor Martins de Oliveira \\ Mestre em Geografia pelo Programa de Pós-Graduação em Geografia \\ da Universidade Estadual de Montes Claros, Brasil \\ igormogeo@gmail.com
}

Luiz Andrei Gonçalves Pereira

Doutor em Geografia (UFU) e professor do Programa de Pós-Graduação em Geografia da Universidade Estadual de Montes Claros, Brasil

luizandreigoncalves@yahoo.com.br

\begin{abstract}
Resumo
O projeto Jaíba está localizado na região do Norte do estado de Minas Gerais. Esse empreendimento é um dos maiores projetos de irrigação do país, voltado para a produção de frutas. No comércio internacional, seis empresas do Jaíba atuaram na exportação de limão, com destaque para o continente europeu e para o Oriente Médio. Diante disso, este trabalho tem como objetivo é analisar a dinâmica espacial da logística de transportes e do comércio internacional por meio dos fluxos de exportações de mercadorias do setor de fruticultura na região produtiva do Jaíba, no período de 2000 a 2017 . A ascensão de regiões produtivas como a do Jaíba, especializadas na fruticultura irrigada, está diretamente relacionada à aplicação da ciência, da técnica, da informação e da circulação. A logística de transporte se mostrou uma prática fundamental para o desenvolvimento do comércio internacional da região produtiva.
\end{abstract}

Palavras-chave: Região Produtiva do Jaíba, Logística de Transportes, Comércio Internacional, Fruticultura.

\begin{abstract}
The Jaíba project is located in the northern region of the state of Minas Gerais. This venture is one of the most significant irrigation projects in the country, focused on fruit production. In international trade, six companies from Jaíba were active in the exportation of lemon, highlighting the European continent and the Middle East. Given this, this paper aims to analyse the spatial dynamics of transport logistics and international trade through the flow of merchandise exports from the fruit sector in the productive region of Jaíba, from 2000 to 2017. The rise of regions The productive activities such as Jaíba, specialised in irrigated fruit farming, are directly related to the application of science, technique, information and circulation. Transport logistics proved to be a fundamental practice for the development of international trade in the productive region.
\end{abstract}

Keywords: Jaiba Production Region, Transport Logistics, International Trade, Fruit Farming. 


\section{INTRODUÇÃO}

O processo de modernização da agricultura brasileira se iniciou na década de 1960, mas foi a partir da década de 1990, em decorrência da neoliberalização econômica, da regulação híbrida do território e do protagonismo das políticas das grandes empresas, que se configurou o agronegócio globalizado do Brasil. Desde então, diferentes processos de regionalização produtiva sob o comando do agronegócio globalizado têm-se formado no país, tendo como um dos principais objetivos sua inserção cada vez mais competitiva nos mercados internacionais (CASTILLO et al., 2016). Nessa disputa pela competitividade no mercado externo, as empresas/corporações se destacam como os atores globais controladores das redes e dos fluxos (SANTOS, 1997).

Na contemporaneidade, em decorrência da globalização, a organização espacial do território escapa de toda regulação interna, trazendo aos agentes econômicos um sentimento de instabilidade e de contínua competição. Nesse processo, o mercado surge como uma arena de numerosos movimentos e de conflitos fundados sob a lei do valor e da circulação (SANTOS, 1997).

No bojo da Globalização, o processo de circulação é uma das bases de diferenciação geográfica e um componente central do sistema capitalista, tornando-se um importante viés de análise do mundo, a partir, sobretudo, do acelerado crescimento dos fluxos de mercadorias, pessoas, capitais e, principalmente, informação, cujo desenvolvimento tem contribuído para a (re)configuração espacial contemporânea em um contexto da formação de territórios e das regiões produtivas, notadamente, aquelas voltadas para o mercado externo (ARROYO, 2001; BLANCO, 2015). O desenvolvimento do sistema de circulação (transportes, informação e comunicação), que impõe à escala mundial a possibilidade da integração produtiva de territórios cada vez mais distantes, está diretamente ligado o desenvolvimento da logística, estágio atual do processo de circulação, compreendida como o conjunto de processos, de procedimentos e de ações que visa à organização e otimização dos movimentos de produtos, desde a fonte de matéria-prima, o fornecimento de insumos até o consumo final.

A circulação como instância geográfica não se restringe apenas ao movimento (transporte) de produtos, mas também à circulação de capital, informação e trabalho, contribuindo, dessa forma, para o processo de acumulação (SILVEIRA, 2015). A dinâmica da circulação no comércio internacional torna-se um elo das redes de interações e das trocas econômicas. A lógica do capital e das empresas se pauta na competitividade, levando as empresas a se inserirem no mercado global por meio do aumento de sua esfera de influência e de ação (SANTOS, 2007). A ação do capital atua ativamente no ordenamento territorial e na formação da especialização produtiva dos lugares (BLANCO, 2015). Os processos produtivos referem-se a todas as ações voltadas à geração e à 
distribuição do conjunto de bens e serviços, visando atender às necessidades sociais e aos desejos de rentabilidade.

Nesse contexto, o desenvolvimento do sistema técnico, científico e informacional favoreceu a difusão dos transportes e da comunicação em conformidade com o avanço e a expansão capitalista; esse complexo processo cria condições para que os lugares se especializem. A especialização produtiva dos lugares, na visão de Arroyo (2001), gera inúmeros processos/resultados, entre os principais, pode-se citar o desenvolvimento de atividades secundárias, de novos circuitos espaciais produtivos e de círculos de cooperação no espaço, além da produção stricto sensu e da maior divisão interna do trabalho. Os lugares especializados são, um resultado direto do processo de circulação. Assim, aqueles dotados de maior infraestrutura têm a capacidade de oferecer e proporcionar maior rentabilidade; esse é um fator de suma importância para a produção do espaço na globalização (ARROYO, 2001).

A produtividade espacial demonstra uma hierarquia entre os lugares que são criados e recriados em função de um movimento nacional e mundial de bens e serviços. As regiões produtivas redefinem as dinâmicas do território em que são instaladas, articulam diferentes atores públicos e privados, para criarem condições favoráveis à produtividade e à competitividade. $\mathrm{O}$ modo de agir das regiões produtivas é paradigmático das seletividades territoriais que surgem em decorrência da economia global sobre o local, bem como das respostas que o território é capaz de produzir para responder às exigências vindas do mercado, sobretudo, do global.

Neste contexto de especialização produtiva dos territórios, o projeto Jaíba localizado norte do estado de Minas Gerais se destaca como uma região produtiva especializada na fruticultura irrigada cuja produção é comercializada em mercados locais, regionais, nacionais e em mercados externos. O projeto Jaíba é um dos maiores projetos de fruticultura irrigada do país. Atualmente, sua cesta de produtos, oriundos da produção permanente é composta por 14 produtos destacando-se a produção de banana, limão, manga, entre outros.

Entre os produtos presentes no mercado nacional, as frutas possuem uma das cadeias produtivas de maior complexidade operacional, pois o espaço, o tempo e as condições dos transportes utilizados determinarão a qualidade e a rentabilidade do produto final. As frutas começam a perder qualidade no momento da colheita, por isso, a necessidade da eficiência dos processos logísticos, principalmente, nas etapas da pós-colheita (transporte, armazenamento, comercialização).

Para realizar e manter seu fluxo de comércio, a região produtiva do Jaíba desenvolveu uma considerável rede de circulação (material e imaterial), sobretudo, a partir dos anos 2000 quando se iniciou seu processo de internacionalização através das dinâmicas espaciais dos processos de importações e exportações. Contudo, mesmo com sua rede de circulação, a região produtiva do Jaíba enfrenta limitações/gargalos no campo logístico, notadamente, devido a sua localização distante 
geograficamente dos grandes centros de distribuição, principalmente, dos recintos alfandegados utilizados no/para o comércio internacional.

No contexto da internacionalização econômica no comércio global, a problemática deste estudo se pauta na seguinte questão: como o setor de fruticultura na região produtiva do Jaíba organiza-se em rede de fluxos internacionais por meio da logística de transportes, das exportações de mercadorias no espaço geográfico? Diante dessa problemática, objetivo deste trabalho é analisar a dinâmica espacial da logística de transportes e do comércio internacional por meio dos fluxos de exportações de mercadorias do setor de fruticultura na região produtiva do Jaíba, no período de 2000 a 2017.

\section{PROCEDIMENTOS METODOLÓGICOS}

Para a execução deste estudo, seguiram-se os seguintes procedimentos metodológicos: iniciou-se com a revisão bibliográfica por meio do uso de textos publicados em livros, artigos, dissertações, teses, sites especializados, dentre outros. Na segunda etapa, realizou-se a coleta de dados secundários, optando-se pela utilização de três bases de dados, quais sejam: para a caracterização e espacialização da produção frutícola dos municípios que compõem a região produtiva do Jaíba, utilizou-se a Produção Agrícola Municipal - PAM - culturas permanentes, disponibilizada pelo Instituto Brasileiro de Geografia e Estatísticas - IBGE, uma vez que todas as frutas exportadas pela região fazem parte dessa categorização. Para a identificação das empresas localizadas na região do Jaíba e que atuam no mercado internacional, utilizou-se o Cadastro de Empresas Exportadoras e Importadoras do Ministério da Indústria, Comércio Exterior e Serviços - MDIC referente aos anos de 2000 a 2017. Nesse cadastro, foi possível a identificação de 6 empresas exportadoras. Para essa identificação, considerou-se as empresas cuja Classificação Nacional de Atividades Econômicas CNAE's estejam vinculada as atividades de cultivo/processamento/distribuição de frutas de lavouras permanentes, e participaram, em algum momento do espaço amostral deste trabalho, do comércio internacional. Para a identificação dos países importadores dos produtos do Jaíba, bem como para a análise e espacialização do seu comércio internacional, utilizou-se a base de dados do MDIC, disponibilizada na plataforma eletrônica do AliceWeb2 ${ }^{1}$. Para a identificação dos produtos comercializados, foi utilizado como base o Sistema Harmonização- SH (SH4); considerando os códigos 0801 a 0814.

Após o levantamento dos dados, iniciou-se a terceira etapa da pesquisa que correspondeu à análise dos dados. Nessa etapa, foi realizada a manipulação/cruzamento dos dados quantitativos, por meio da criação de bancos de dados nos softwares EXCEL 2007 e Arcgis 10.2 (licenciado pelo

\footnotetext{
${ }^{1}$ A plataforma AliceWeb saiu do ar em julho de 2018, sendo substituída pela plataforma Comex Sat. 
laboratório de Geoprocessamento...acrescentar a identificação após a avaliação). Por fim, realizou-se a elaboração de gráficos, quadros, tabelas e mapas temáticos da espacialização da logística de transportes nacionais e internacionais, bem como dos mercados destinos das exportações realizadas pela Região Produtiva. Para a elaboração do material cartográfico, utilizou-se o software Arcgis 10.2; as bases cartográficas utilizadas foram disponibilizadas pelo IBGE e pela plataforma Natural Earth. As imagens utilizadas foram extraídas do Google Earth Pró e georreferenciadas no Arcgis 10.2.

Na complementação da pesquisa dos dados secundários foram realizados trabalhos de campo na Região Produtiva; em um primeiro momento, para observar a estrutura de plantação/ produção e a logística de transportes. Depois dessa etapa, foram elaborados roteiros de entrevistas semiestruturadas $^{2}$ que foram aplicadas aos representantes das empresas exportadoras com domicílio fiscal em Jaíba e em Matias Cardoso. O intuito das entrevistas foi verificar as percepções dos agentes econômicos atuantes nos municípios da região produtiva acerca da logística intra e interprojeto.

Além da introdução e das considerações finais, este artigo foi estruturado em três partes, quais sejam: O Projeto Jaíba: caracterização da área de estudo, onde se apresentou o projeto de irrigação através de um breve histórico de sua implantação, objetivos e de sua rede de infraestrutura. A segunda parte intitulada: O Projeto Jaíba nas redes de comércio: a Geografia das Exportações, analisou-se a série histórica das exportações na região produtiva por meio da identificação e espacialização do fluxo de produtos e capitais. Por fim, na terceira parte denominada: As empresas exportadoras da Região Produtiva do Jaíba: breves considerações acerca da logística da fruticultura, apresentou-se breves considerações da logística aplicada à fruticultura destinada à exportação, na perspectiva das empresas exportadoras.

\section{O PROJETO JAÍBA: CARACTERIZAÇÃO DA ÁREA DE ESTUDO}

O Norte de Minas é uma região singular, diferenciada das demais no contexto do estado (PEREIRA; RIBEIRO 2005). Formada por 89 municípios suas características físicas, culturais, sociais, econômicas e a baixa incorporação tecnológica definem sua singularidade; além de tudo isso, o Norte de Minas está no limite de duas macrorregiões, o Sudeste e o Nordeste (SANTOS; SILVA, 2010). A região é banhada pela bacia do São Francisco, em cuja margem foi implantado importantes área de fruticultura irrigada, como exemplo, os projetos Pirapora, Gorutuba, Lagoa Grande e Jaíba, localizados nos municípios de Pirapora, Nova Porteirinha, Janaúba e Jaíba/ Matias Cardoso, respectivamente, como demonstrado na Figura 1. Essas regiões produtivas são especializadas na

\footnotetext{
${ }^{2}$ Esta pesquisa foi submetida ao Comitê de Ética da universidade a qual está vinculada. Após a avaliação, será inserido o número do parecer.
} 
fruticultura irrigada, voltadas, principalmente, para o abastecimento interno e pequeno percentual da produção para a exportação, como é o caso do Projeto Jaíba.

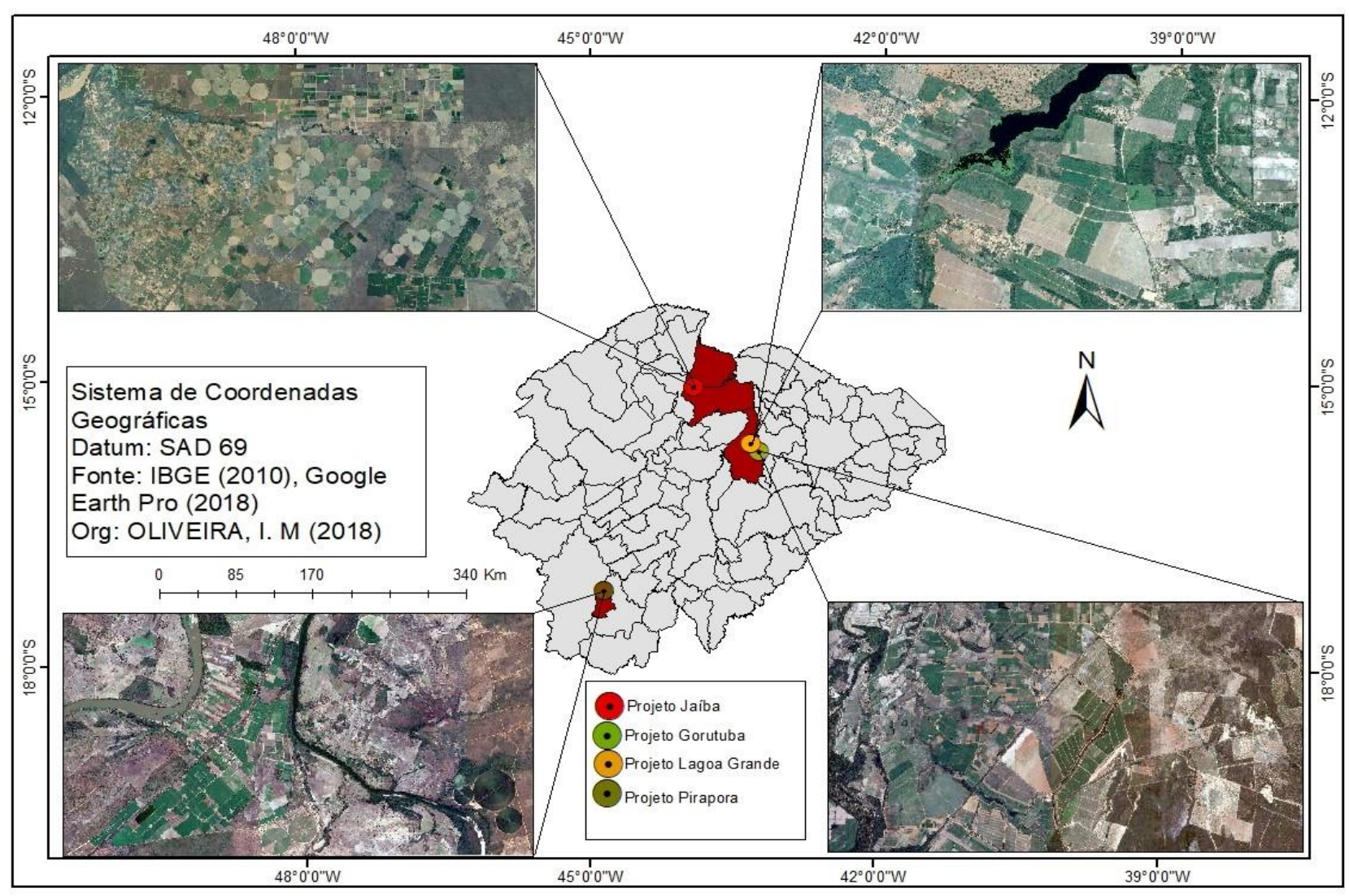

Figura 1 - Localização dos Projetos de Irrigação no Norte de Minas Gerais.

Fonte: Oliveira, 2018.

O Projeto Jaíba está localizado nos municípios de Jaíba e de Matias Cardoso (na microrregião de Janaúba), com sede no distrito de Mocambinho (no município de Jaíba) (como demonstrado na Figura 2), à margem direita do rio São Francisco e à margem esquerda do rio Verde Grande.

A área do projeto abrange uma extensão de 230 mil hectares, sendo 100 mil irrigáveis, 130 mil hectares de área de sequeiro. O projeto contém $248.03 \mathrm{~km}$ de canais de distribuição de água (Figuras 3), $521 \mathrm{~km}$ de estradas de serviços, $3 \mathrm{~km}$ de rede de drenagem, 11 estações de bombeamento de água; seu sistema energético é formado por 13 subestações de distribuição de energia, sendo 10 subestações da Companhia de Desenvolvimento dos Vales do São Francisco e do Parnaíba CODEVASF, com capacidade total de 52.900 KVA, e 3 subestações da Companhia Energética de Minas Gerais - CEMIG, cuja capacidade total é de 37.500 KVA, como demonstrado na Figura 3 (DUARTE; TAVARES, 2001, PEREIRA; FERREIRA, 2016; DIJ, 2017). Há também no projeto o aeroporto de Mocambinho (Figura 3). Na atualidade nenhuma empresa opera voos comerciais regulares nesse aeroporto. 


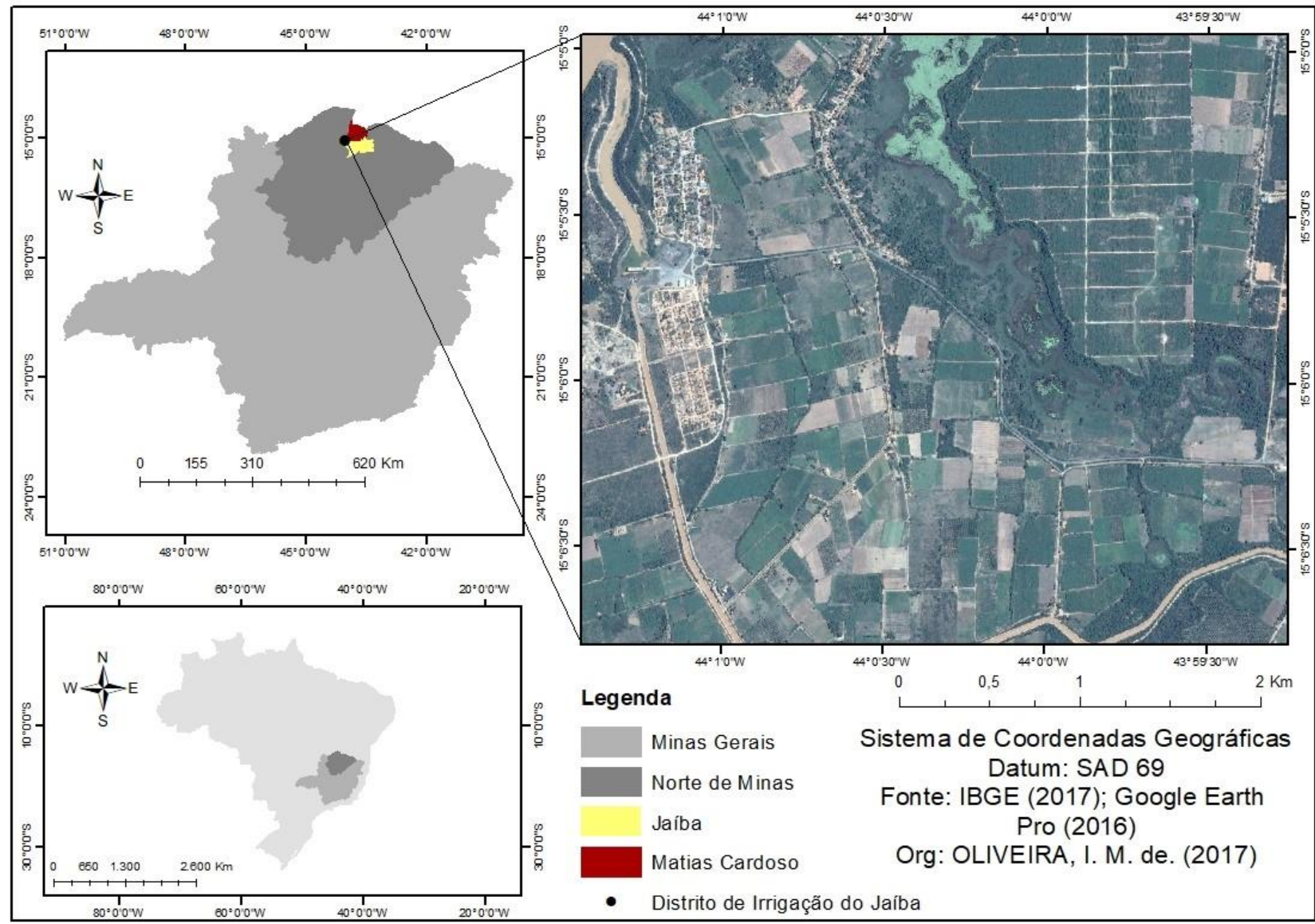

Figura 2 - Localização do Distrito de Irrigação do Jaíba, Minas Gerais.

Fonte: Oliveira, 2017.

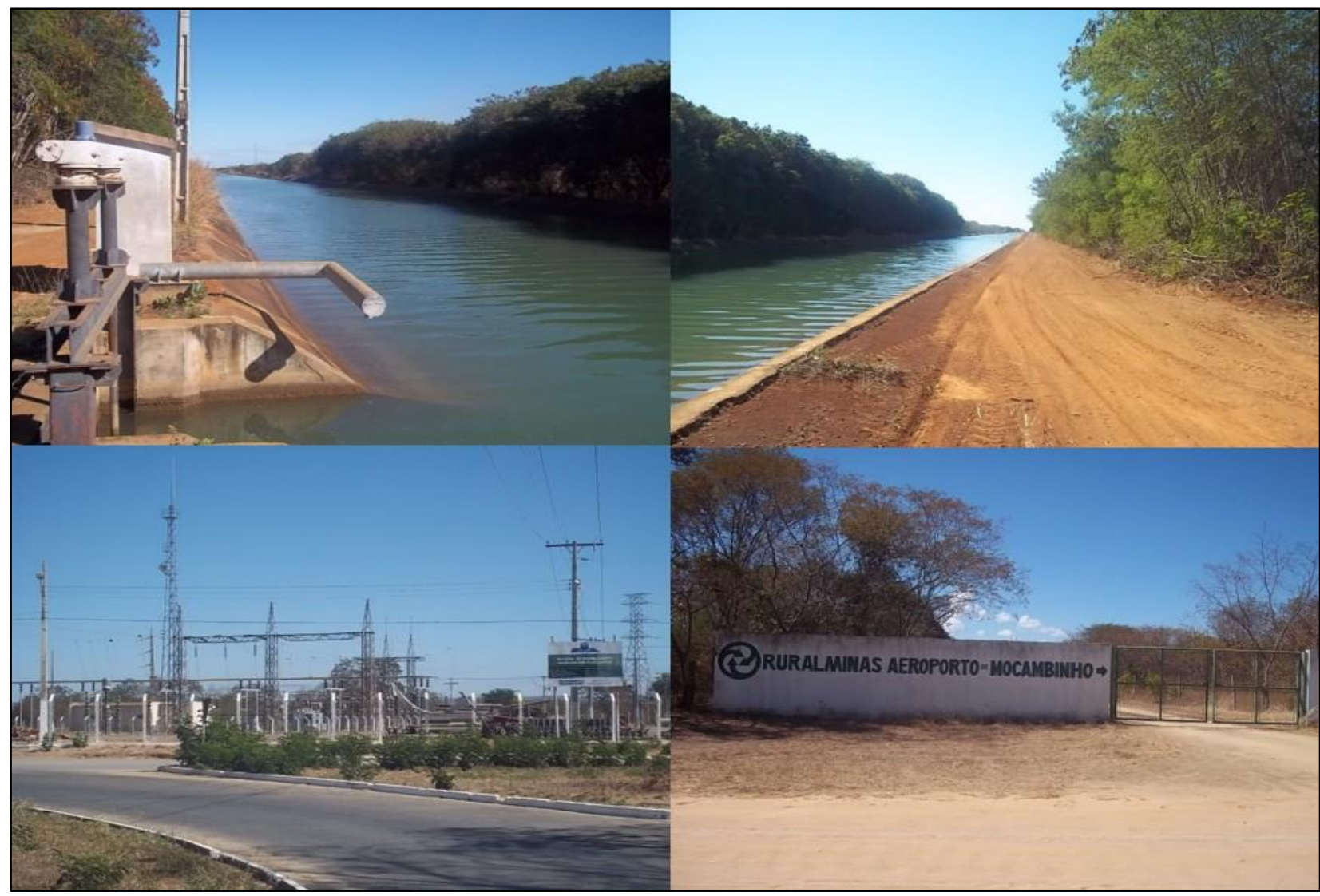

Figura 3 - Mosaico: Infraestrutura (canais de irrigação, sistema elétrico e aeroporto).

Fonte: Oliveira, 2018. 
O contexto de criação do projeto Jaíba está diretamente relacionado às políticas públicas de desenvolvimento regional. A partir da década de 1930, com o advento da crise mundial, houve a ascensão do pensamento Keynesiano na política americana trazendo para o cerne do governo as questões relacionadas ao planejamento e desenvolvimento regional, no sentido de pensar estratégias para impulsionar o crescimento e desenvolvimento econômico (RODRIGUES, 2001).

Rodrigues (2001), Pereira e Ferreira (2016) contextualizam a implantação do Jaíba a partir projetos de desenvolvimento regional implantados em outros países que serviram de modelo para o Projeto Jaíba, quais sejam: o Tennessee Valley Authority, agência de fomento Norte Americana, criada em 1933 com o objetivo de planejar a utilização dos recursos hídricos, a política agrícola, energética e de transporte na região do Tennessee; e o Vale do Mezzogiorno, criado na Itália em 1950, visando estimular a industrialização no sul do país por meio da combinação de política agrícola, uso da água e incentivos fiscais.

A concepção do projeto teve início na década de 1950, idealizado no cerne das políticas de desenvolvimento regional dos anos JK, porém, a implantação de sua infraestrutura iniciou em 1972. Nas palavras de Santos e Silva (2010), os principais objetivos para a implantação do projeto na região do Norte de Minas foram: alargar a fronteira agrícola do país, integrando a região em um processo de desenvolvimento por meio da agroindústria; aumento da renda média da população local por meio da implantação de indústrias, agroindústrias e empreendimentos agropecuários; introdução de novas tecnologias na agricultura local e, por fim, criação de um novo polo agropecuário para abastecer parte da Região Sudeste.

Em meados da década de 1980, no discurso oficial, o projeto seria uma ferramenta estratégica de/para o desenvolvimento regional, objetivando a minimização dos problemas socioeconômicos comuns em todo o Norte do estado. Dessa maneira, para atender o caráter social, a etapa I do projeto foi destinada aos pequenos produtores, em consonância com a lei 6.662/1979, que dispõe sobre a Política Nacional de Irrigação (MARTINS et al., 2008; MARTINS, 2008). Em 1988, ocorreu a criação do Distrito de Irrigação do Jaíba, “entidade que congrega os irrigantes assentados na área de abrangência do Perímetro Irrigado de Jaíba - Etapa I. É uma associação civil, de direito privado, sem fins lucrativos, com personalidade jurídica, patrimônio e administração próprios” (DIJ, 2017, s/p). Destaca-se, nesse contexto, a atuação da $\operatorname{CODEVASF}^{3}$, na gestão das ações do projeto (MARTINS et al., 2008). A criação do Distrito de Irrigação foi uma alternativa encontrada pelo governo para que houvesse a descentralização da gestão, saindo das mãos do setor público e, gradativamente, passando para o privado (DUARTE; TAVARES, 2001).

\footnotetext{
${ }^{3}$ A CODEVASF é uma empresa pública vinculada ao Ministério da Integração Nacional que promove o desenvolvimento e a revitalização das bacias dos rios São Francisco, Parnaíba, Itapecuru e Mearim com a utilização sustentável dos recursos naturais e estruturação de atividades produtivas para a inclusão econômica e social (CODEVASF, 2017 s/p. disponível em: https://www2.codevasf.gov.br/empresa)
} 
O Projeto foi previsto para quatro etapas, a etapa I, a princípio, voltada para a agricultura familiar, encontra-se finalizada. A etapa II, também encontra-se finalizada, e atende exclusivamente o setor empresarial. Em contrapartida, as etapas III e IV estão em processo de implantação (FONSECA et al., 2011). Em uma primeira análise baseada na literatura especializada, entende-se que, conquanto tenha uma grande área de produção (parte ainda não finalizada), o Projeto Jaíba ainda não atingiu o grau técnico, produtivo, de intensidade e extensão do fluxo de circulação encontrado em outras áreas do país como, por exemplo, Petrolina (PE) e Juazeiro (BA). No que se refere a cesta de produtos da região, A PAM dos municípios do Projeto Jaíba, apresenta 14 produtos de cultura permanente, sendo eles: abacate, banana, café canephora, café arábica, coco da baía, goiaba, laranja, limão, mamão, manga, maracujá, tangerina, urucum e uva.

Embora a região Norte de Minas tenha, nas últimas décadas, se especializado no mercado frutícola, a literatura especializada demonstra que apenas um intenso e moderno sistema de produção não é suficiente para o desenvolvimento de uma matriz comercial eficaz e eficiente de âmbito global. Faz-se necessário o desenvolvimento de uma infraestrutura que comporte o sistema de comunicação, de transporte e de armazenamento (MARTINS; CAIXETA FILHO, 1998).

No Norte de Minas, os investimentos em infraestrutura rodoviária, principal via de transporte do país, se iniciaram no pós-década de 1960, a partir da inserção da região na área de influência da Sudene. A partir da primeira década de 2000, a Região Produtiva do Jaíba iniciou seu processo de internacionalização, firmando redes de comércios por meio da importação de produtos voltados, sobretudo, para o setor agroindustrial, notadamente, o ligado à fruticultura irrigada, e pelas exportações de produtos oriundos do mesmo setor.

Finalizada a caracterização do Projeto Jaíba, a próxima seção deste trabalho, analisar-se-á o fluxo de exportação de produtos oriundos da Região Produtiva do Jaíba, identificando os principais parceiros comerciais, seu respectivo fluxo de comércio, os principais recintos alfandegados e a logística aplicada no setor.

\section{O PROJETO JAÍBA NAS REDES DE COMÉRCIO: A GEOGRAFIA DAS EXPORTAÇÕES}

O desenvolvimento e a difusão dos transportes e das comunicações, por meio das dinâmicas espaciais da logística, favoreceram a expansão do capitalismo que criou as condições favoráveis para a especialização produtiva dos territórios, anteriormente isolados, como é o caso da região produtiva do Jaíba, estabelecendo as condições favoráveis à crescente divisão territorial do trabalho. Esse processo é gradativamente acelerado com o desenvolvimento do meio técnico, científico e informacional, gerando a intensificação dos intercâmbios que se configuram em espaços cada vez mais amplos. Para Santos (2006), os lugares, especializados, tende a se desenvolveram a 
partir de sua capacidade de oferecer rentabilidades, que por sua vez estão condicionadas ao nível técnico (infraestrutura e organizacional). As redes técnicas, nesse contexto, favoreceram a difusão da tecnologia no território a partir das relações comerciais que se difundem mais rápida e largamente do que em épocas anteriores (SANTOS, 2006).

$\mathrm{Na}$ contemporaneidade, a formação e a consolidação dos circuitos globais de abastecimento de alimentos promovem a descentralização dos fluxos e reestruturação da produção em bases locais, como discutido anteriormente, a especialização produtiva dos lugares possibilita a inserção de algumas regiões (anteriormente isolados devido sua localização geográfica) nos circuitos superiores da economia (SILVA, 2001). Silva (2001) adverte sobre a necessidade de se observar o grau de participação das regiões no mercado mundial. A região produtiva do Jaíba se enquadra nesse contexto de especialização e inserção no mercado global no segmento da fruticultura e de seus derivados.

Nos últimos anos, a Região Produtiva do Jaíba tem se especializado em produção de frutas, sobretudo, a partir de sua inserção nas redes de comércio internacional. O processo de internacionalização do Projeto Jaíba se iniciou no ano de 2001, quando uma empresa ${ }^{4}$ com domicílio fiscal no município de Matias Cardoso, exportou 95.424 quilogramas de frutas para o Canadá. No ano seguinte, 2002, um novo fluxo foi realizando, 38.976 de frutas foram exportadas, como representado na Tabela 1. Diretamente, esses foram os únicos fluxos de produtos exportados pelas empresas com domicilio fiscal no município de Matias Cardoso. Entre os anos de 2003 a 2008, nenhum fluxo de exportação foi realizado pelos municípios do Projeto Jaíba.

Tabela 1 - Exportações no município de Matias Cardoso, fluxos acumulados no período de 2000 a 2017 (US\$/FOB e kg).

\begin{tabular}{cccccc}
\hline Ano & $\begin{array}{c}\text { Código } \\
\text { SH4 }\end{array}$ & Descrição do SH4 & $\begin{array}{c}\text { País } \\
\text { Destino }\end{array}$ & US\$ FOB & $\begin{array}{c}\text { Peso Líquido } \\
\text { (kg) }\end{array}$ \\
\hline 2001 & 0804 & $\begin{array}{c}\text { Tâmaras, figos, ananases (abacaxis), abacates, } \\
\text { goiabas, mangas e mangostões, frescos ou secos }\end{array}$ & Canadá & 83.496 & 95.424 \\
2002 & 0804 & $\begin{array}{c}\text { Tâmaras, figos, ananases (abacaxis), abacates, } \\
\text { goiabas, mangas e mangostões, frescos ou secos }\end{array}$ & Canadá & 19.488 & 38.976 \\
\hline
\end{tabular}

Fonte: MDIC, 2018. Org. Oliveira, 2018.

Foi somente a partir do ano 2009 que a Região do Jaíba se destacou como uma região exportadora (ano de maior fluxo de capital e produtos importados), doravante a entrada das empresas com domicílio fiscal no município de Jaíba, inseriu-se no comércio internacional por meio das vendas de produtos da fruticultura. Entre os anos de 2001 a $2017^{5}$, os municípios do projeto produziram

\footnotetext{
${ }^{4}$ Optou-se por não divulgar os nomes das empresas.

${ }^{5}$ Até o ano 2000 a quantificação de algumas frutas, tais como: abacate, caqui, figo, goiaba, laranja, limão, maçã, mamão, manga, maracujá, marmelo, pera, pêssego e tangerina eram contabilizadas por mil frutos, a banana por sua vez, era
} 
2.969.605 toneladas de frutas (sendo 1.900.027 toneladas produzidas pelo município de Jaíba e 1.069.578 por Matias Cardoso); no mesmo período, 18.962 .762 quilogramas de frutas foram exportadas, isso corresponde a $0,64 \%$ do volume produzido. O município de Jaíba respondeu pelo maior fluxo de produtos exportados. Do total de frutas produzidas pelo município, 0,99\% foi comercializado no mercado externo. Da produção permanente do município de Matias Cardoso, apenas $0,012 \%$ foi exportado. O volume de produtos exportados pela região produtiva está representado na Figura 4 que demonstra o volume em quilogramas e a receita dos produtos exportados nas duas fases citadas: o período de inserção do município de Matias Cardoso (2001 e 2002); e o segundo momento, a expansão da rede de comércio externo a partir da participação das empresas de domicílio fiscal no município de Jaíba.

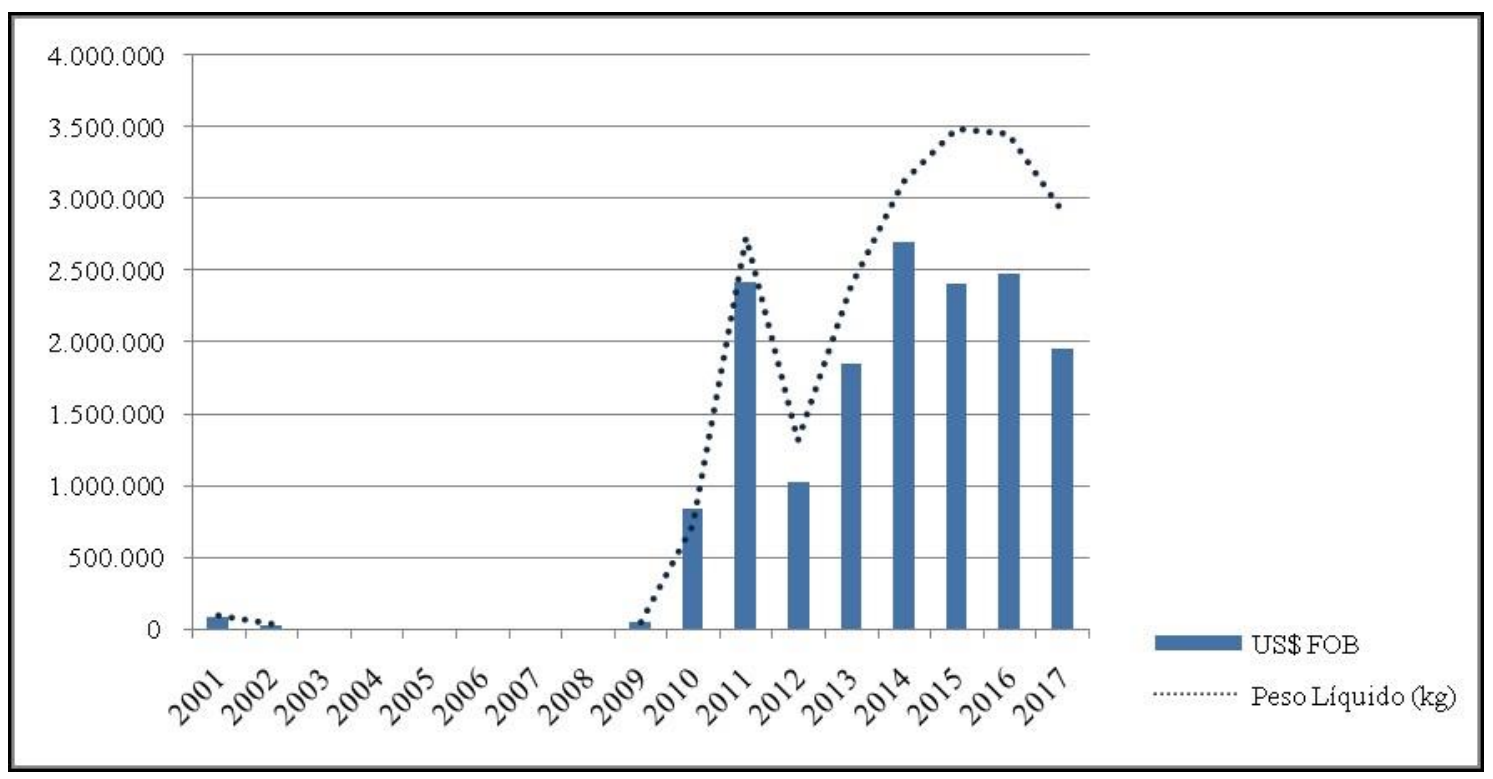

Figura 4 - Exportações: Municípios do Projeto Jaíba, 2000 - 2017.

Fonte: MDIC, 2018. Org. Oliveira, 2018.

Além da inserção do município de Jaíba nas redes de comércio internacional, o ano de 2009 marcou o ciclo de crescimento da produção agrícola do município, quando se registrou aumento de $47,51 \%$ na produção de frutas se comparado ao ano anterior. Nesse período, registrou-se também o aumento da rentabilização das principais culturas do projeto. A concentração do fluxo de comércio em um setor produtivo (frutícola) corrobora com uma das proposições deste trabalho: a especialização produtiva na região do Jaíba. Nota-se, pela Tabela 2, a existência de um único fluxo de comércio para os Estados Unidos de produtos agrupados no SH4 6802 que não se relacionam com o setor de fruticultura, representando $0,06 \%$ do valor em capital e $0,02 \%$ do volume comercializado. Entende-

quantificada em mil cachos. A partir de 2001, o IBGE padroniza a metodologia de quantificação adotando a "tonelada" como unidade de medida. 
se que essa concentração dos produtos em um único setor produtivo é uma característica da especialização da região produtiva.

Tabela 2 - Exportações no município de Jaíba, fluxos acumulados no período de 2000 a 2017 (US\$/FOB e kg).

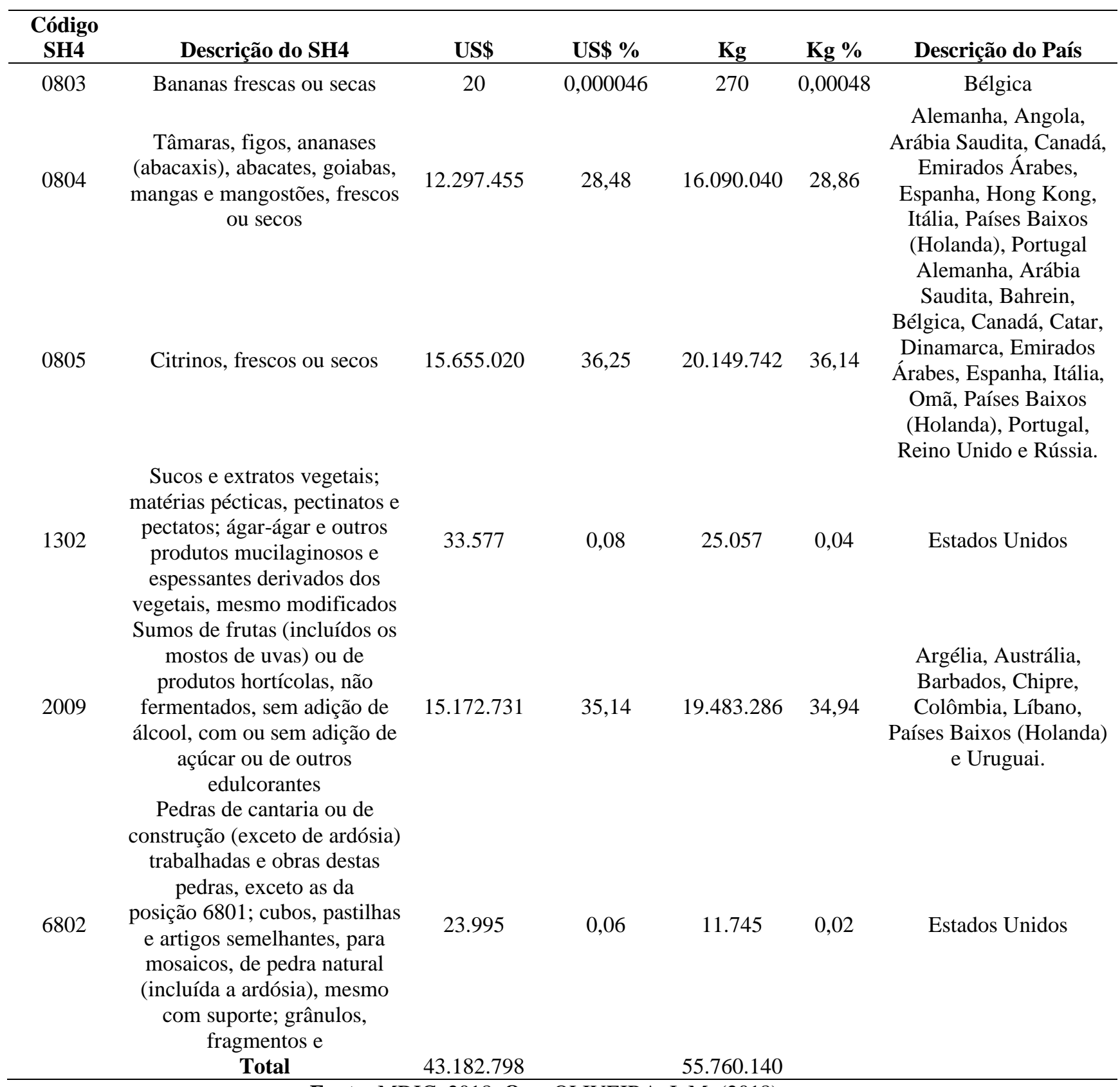
Fonte: MDIC, 2018. Org. OLIVEIRA, I. M. (2018).

Entre os anos de 2000 a 2017 a Região Produtiva manteve uma rede de relações comerciais, por meio das exportações, com 25 países em diferentes continentes, tais como Países Baixos, Reino Unido e Bélgica, que registraram os maiores volumes importados no continente europeu. Esse continente configurou-se como o principal mercado importador dos produtos do Jaíba. Os países Omã, Catar e Emirados Árabes foram os maiores importadores do continente asiático. É importante destacar que naquela região estão localizados os dois maiores produtores mundiais de frutas: China e Índia, isso demonstra o potencial da produção frutífera da região; pode-se inferir, também, a 
existência de barreiras à inserção no mercado daquela região. Nessa mesma direção, é importante destacar a atuação das empresas da região do Jaíba nas redes do mercado do continente americano, Canadá, Colômbia e Estados Unidos concentraram os maiores fluxos em capital de produtos comercializados no continente americano (MDIC, 2018), conforme demonstrado na Figura 5. Sobre o mercado norte americano, é importante destacar sua postura protecionista através da criação de barreiras tarifárias que dificultam a atuação de empresas do circuito inferior ${ }^{6}$ da economia global.

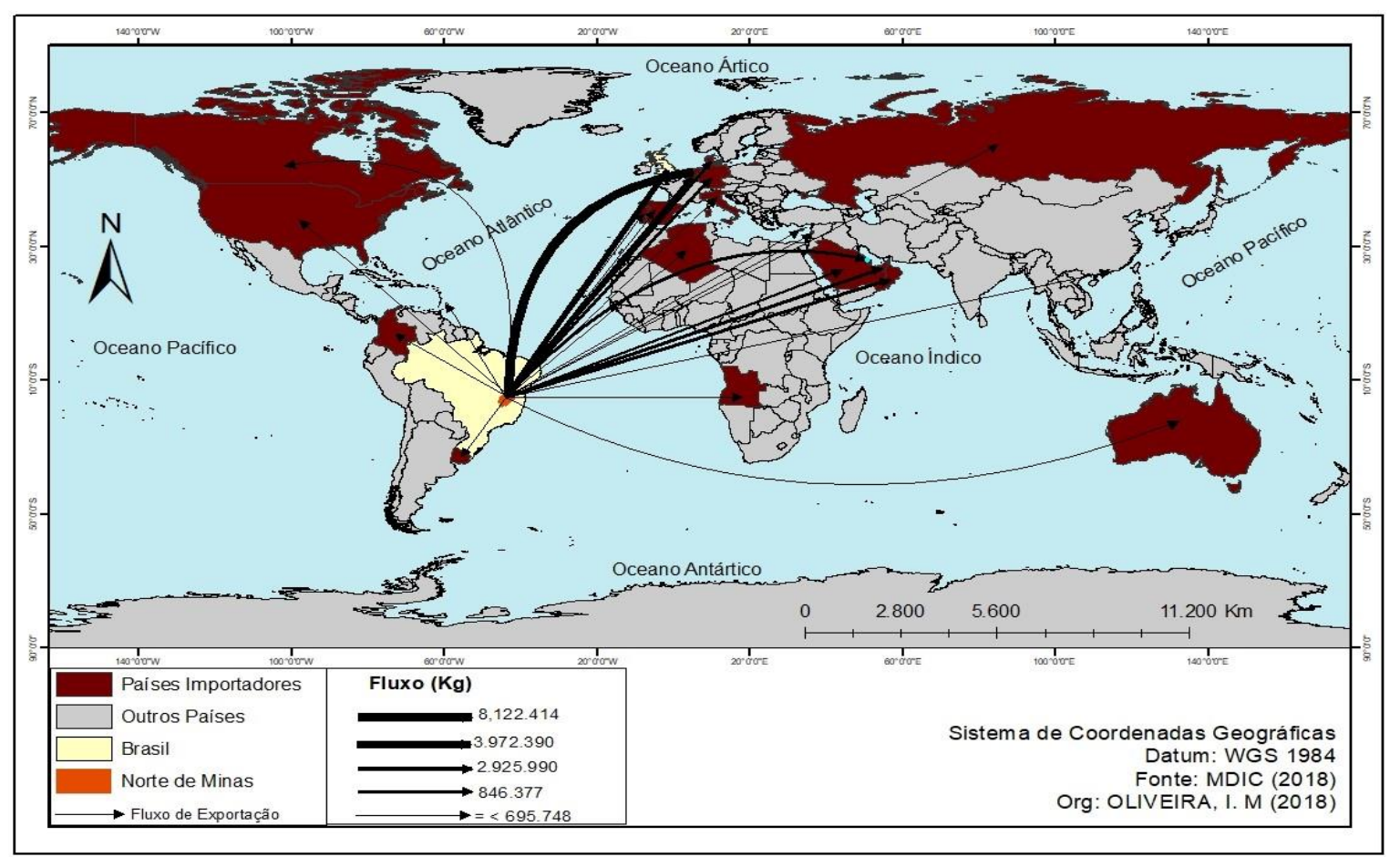

Figura 5 - Exportação do Projeto Jaíba, fluxos acumulados no período de 2000 a 2017 (kg). Fonte: Oliveira, 2018.

As empresas com domicílio fiscal na área de abrangência do Projeto mantiveram, também diferentes relações com os países por meio do comércio em blocos econômicos. Considerando a base de dados do MDIC, foi possível a identificação de diferentes blocos econômicos que importaram produtos da região do Jaíba quais sejam: União Europeia - UE, Mercosul, APEC, SADC, CELAC, ANZCERTA, ALADI, CAFTADR, NAFTA (é importante considerar que um país pode participar de mais de um bloco econômico simultaneamente).

O maior fluxo de produtos exportados teve como destino a União Europeia (MDIC, 2018). O bloco europeu mantém boa relação comercial com o Brasil por meio de acordos comerciais. O Brasil é um dos maiores fornecedores de produtos agrícolas, exportando, em 2012, aproximadamente 9,0 bilhões de dólares, correspondendo a $15 \%$ das importações agrícolas da União Europeia (BRASIL, 2012). Tratando-se exclusivamente dos produtos do Jaíba, foram 17,3 milhões de

\footnotetext{
${ }^{6}$ Vide Santos (1985)
} 
quilogramas de produtos, como frutas frescas, secas, sumos e outros, exportados para o bloco europeu. Esse montante corresponde a $86,31 \%$ de todo o volume de produtos comercializados no período.

O segundo maior fluxo de exportação teve como destino os países que compõem a APEC; foram aproximadamente 343 mil quilogramas de produtos frutícolas e/ou derivados comercializados, com destaque para a Rússia que concentrou 1,7\% de todo o volume exportado pelas empresas localizadas na Região Produtiva. O terceiro maior fluxo de produtos oriundos das lavouras permanentes da Região Produtiva do Jaíba foi para os países que compõem o Nafta, foram 201.717 quilogramas de produtos exportados, os quais geraram 194.827 de dólares de receita.

Embora aproximadamente $90 \%$ do fluxo de comércio do Jaíba tenha-se concentrado em apenas três blocos econômicos, é importante destacar a atuação da região da Região Produtiva no comércio com blocos de menor relevância no cenário econômico mundial, mas que regionalmente contribuem para a maior integração entre os países, como é o caso, por exemplo, de SADC, CELAC e CAFTADR que receberam 0,06, 1,47 e 0,39 \%, respectivamente, do fluxo de mercadoria. Quanto ao fluxo de capital, tal como ocorreu no fluxo de volume por quilogramas, os maiores volumes foram exportados para a União Europeia, APEC, Nafta, como é representado na Figura 6.

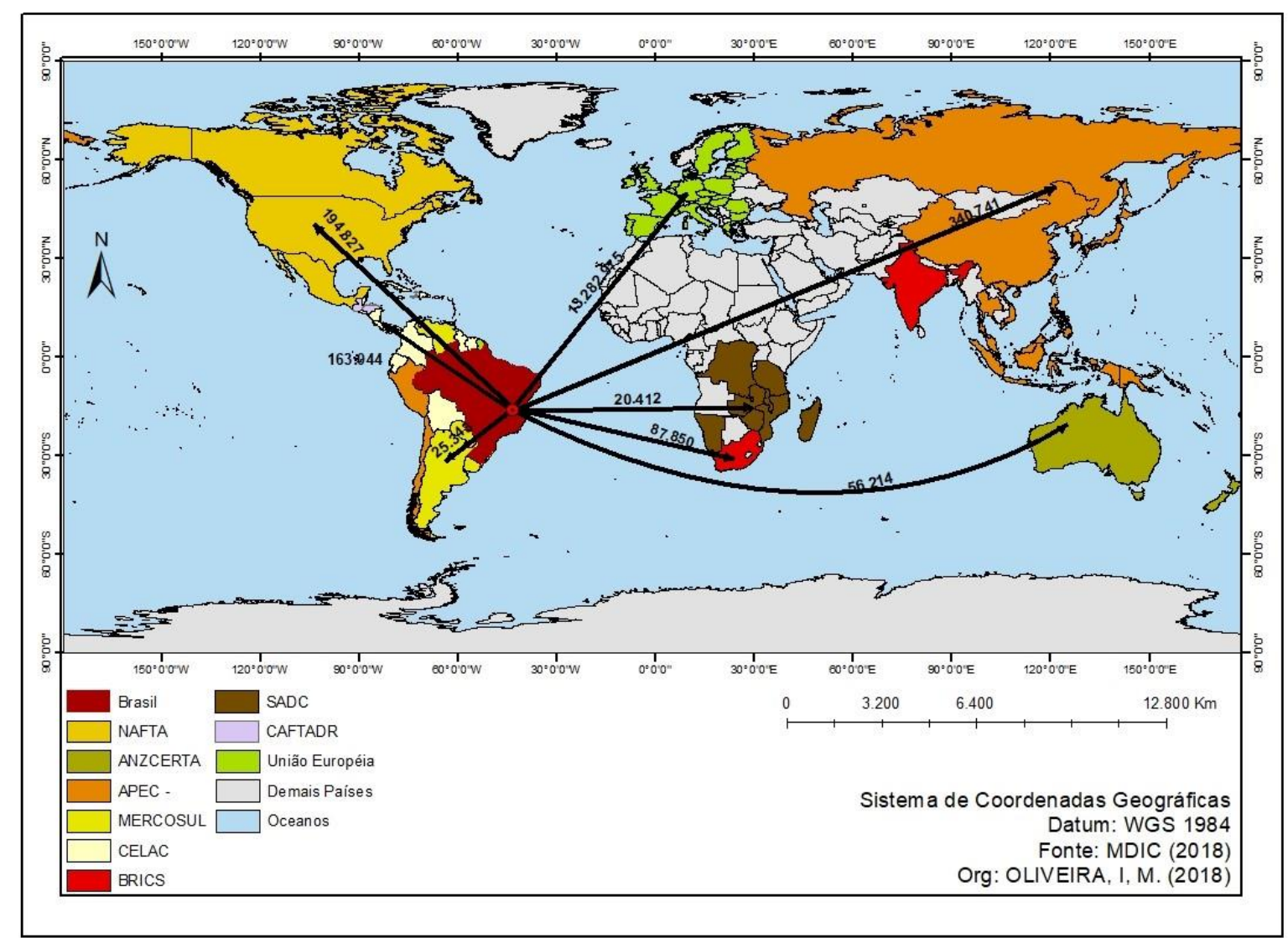

Figura 6 - Projeto Jaíba: Fluxos acumulados por Blocos Econômicos no período de 2000 a 2017 (USS/FOB) Fonte: Oliveira, 2018. 
Os recintos alfandegados, são divididos em zona primária e zona secundária, essas estruturas são elementos fundamentais do/para o comércio internacional, e para a formação das redes, servindo como nós logísticos que ligam as diferentes redes de circulação, aumentando/criando os níveis de competitividade dos agentes econômicos, das cadeias produtivas e das região produtivas (BRAGA; CASTILLO, 2013). No caso específico do Jaíba, para o comércio internacional, são utilizados apenas os recintos de zona primária (portos, aeroportos e pontes de fronteiras). Nas exportações de produtos do Jaíba, além do modal rodoviário utilizado para o transporte interno, foram utilizados dois modais de transporte, o aéreo e o marítimo que concentraram o maior fluxo de produtos transportados.

Embora tenha tido pequena representatividade, o modal aéreo foi utilizado para transportar os produtos destinados a 11 países, totalizando 305.824 quilogramas de produtos transportados, o que representou $1,51 \%$ do fluxo comercializado. Destaque para o fluxo enviado para Portugal, que registrou o maior volume utilizando esse modal. Outro destaque é a Bélgica, conforme a Tabela 3, destino do primeiro e único fluxo de exportação de banana, pelo modal aéreo, da região do Jaíba ${ }^{7}$, ocorrida no ano de 2014, devido à baixa representação do fluxo da banana, isso demonstra um expeço de amostra para verificar a viabilidade da logística para o envio dessa fruta para os mercados globais.

Para David e Stewart (2010), os aeroportos são parte fundamental da infraestrutura de transportes, principalmente, para o comércio internacional. Esse modal é responsável pelo transporte de uma importante parcela de produtos comercializados os quais possuem, geralmente, alto valor agregado, são perecíveis, com baixo peso e dimensionamento. Na última década, conforme Silveira e Quintilhano (2015), o transporte aéreo de cargas registrou aumento de 4\% em escala mundial; os mercados asiáticos registram a maior concentração dos fluxos devido à dinâmica socioeconômica das cadeias produtivas globais.

Na visão de Barat (2012), a expansão do transporte aéreo dependeu da conjugação de uma série de fatores, entre eles: os avanços tecnológicos impulsionados pela crescente competitividade de mercados e mudanças organizacionais de escala nacional e mundial que aumentaram a mobilidade de pessoas e mercadorias. Concomitante a esses fatores, ocorreram investimentos em infraestrutura e a elaboração de uma base normativa para o setor, que contribuiu para os ganhos em eficiência do modal, quais sejam: evolução tecnológica dos equipamentos de voos; melhor utilização dos recursos financeiros, humanos e materiais; evolução dos níveis de produtividade dos empregados das empresas, ajustes à desregulamentação das empresas, permitindo acordos com sindicatos; e firmas inovadoras de relacionamento entre os poderes públicos e as empresas operadoras.

\footnotetext{
${ }^{7}$ Em 2014 uma nova tentativa de exportação de banana foi realizada, desta vez utilizando o modal marítimo. Foram sete toneladas de banana prata enviadas para Portugal.
} 
Tabela 3 - Projeto Jaíba: Exportação por via aérea e marítima de transporte, fluxos acumulados no período de 2000 a 2017 (USS/FOB e kg).

\begin{tabular}{|c|c|c|c|c|c|}
\hline $\begin{array}{c}\text { Descrição da Via de } \\
\text { Transporte }\end{array}$ & Descrição do País & US\$ & US\$ \% & Kg Líquido & $\mathrm{Kg} \mathrm{\%}$ \\
\hline \multirow{11}{*}{ Aérea } & Portugal & 251.882 & 1,59 & 164.636 & 0,81 \\
\hline & Emirados Árabes Unidos & 51.561 & 0,33 & 21.724 & 0,11 \\
\hline & Países Baixos (Holanda) & 45.916 & 0,29 & 43.043 & 0,21 \\
\hline & Canadá & 34.271 & 0,22 & 30.515 & 0,15 \\
\hline & Reino Unido & 21.441 & 0,14 & 16.200 & 0,08 \\
\hline & Alemanha & 18.492 & 0,12 & 9.645 & 0,05 \\
\hline & Espanha & 8.724 & 0,06 & 4.992 & 0,02 \\
\hline & Arábia Saudita & 7.448 & 0,05 & 3.075 & 0,02 \\
\hline & Itália & 5.885 & 0,04 & 10.514 & 0,05 \\
\hline & Hong Kong & 1.845 & 0,01 & 1.210 & 0,01 \\
\hline & Bélgica & 20 & 0,00 & 270 & 0,00 \\
\hline \multirow{26}{*}{ Marítima } & Subtotal & 447.485 & 2,85 & 305.824 & 1,51 \\
\hline & Países Baixos (Holanda) & 6.501 .207 & 41,14 & 8.079 .371 & 39,76 \\
\hline & Reino Unido & 3.252 .645 & 20,58 & 3.956 .190 & 19,47 \\
\hline & Bélgica & 1.753 .781 & 11,10 & 2.925 .720 & 14,40 \\
\hline & Dinamarca & 588.008 & 3,72 & 846.377 & 4,17 \\
\hline & Omã & 557.306 & 3,53 & 695.748 & 3,42 \\
\hline & Catar & 404.762 & 2,56 & 473.503 & 2,33 \\
\hline & Alemanha & 348.455 & 2,21 & 510.661 & 2,51 \\
\hline & Bahrein & 278.835 & 1,76 & 338.871 & 1,67 \\
\hline & Emirados Árabes Unidos & 268.517 & 1,70 & 331.800 & 1,63 \\
\hline & Líbano & 240.914 & 1,52 & 301.131 & 1,48 \\
\hline & Espanha & 200.710 & 1,27 & 341.334 & 1,68 \\
\hline & Itália & 181.326 & 1,15 & 292.572 & 1,44 \\
\hline & Arábia Saudita & 131.317 & 0,83 & 168.000 & 0,83 \\
\hline & Colômbia & 124.272 & 0,79 & 216.126 & 1,06 \\
\hline & Canadá & 102.984 & 0,65 & 134.400 & 0,66 \\
\hline & Chipre & 90.362 & 0,57 & 100.403 & 0,49 \\
\hline & Rússia & 87.850 & 0,56 & 73.143 & 0,36 \\
\hline & Estados Unidos & 57.572 & 0,36 & 36.802 & 0,18 \\
\hline & Austrália & 56.219 & 0,36 & 67.329 & 0,33 \\
\hline & Argélia & 54.007 & 0,34 & 51.924 & 0,26 \\
\hline & Uruguai & 25.343 & 0,16 & 25.860 & 0,13 \\
\hline & Angola & 20.412 & 0,13 & 10.580 & 0,05 \\
\hline & Portugal & 14.121 & 0,09 & 23.814 & 0,12 \\
\hline & Barbados & 13.429 & 0,08 & 12.164 & 0,06 \\
\hline & Subtotal & 15.354.354 & 97,16 & 20.013 .823 & 98,49 \\
\hline Total & & 15.801.839 & $100 \%$ & 20.319.647 & $100 \%$ \\
\hline
\end{tabular}

Fonte: MDIC, 2018. Org. Oliveira, (2018). 
No processo de exportação dos produtos da região produtiva do Projeto Jaíba, foram utilizados cinco aeroportos, quais sejam: Aeroporto de São Paulo que concentrou o maior fluxo monetário, foram 301.915 dólares em produtos exportados; de Confins, foram transportados 89.386 dólares em valores, o que representou 19,98\% do total comercializado. O aeroporto de Salvador se destaca como o terceiro recinto mais utilizado, concentrando $5,02 \%$ do volume trafegado (22.458 dólares); dos aeroportos do Rio de Janeiro e Campinas foram transportados 18.009 e 15.717 dólares em produtos, conforme demonstrado na Figura 7.

No tocante ao fluxo de exportação por quilogramas, observa-se, por meio da Figura 8, que o aeroporto de São Paulo recebeu o maior volume de produtos (206.029 quilogramas); Confins foi utilizado para transportar 56.850 quilogramas de mercadorias; do aeroporto de Salvador foram enviados 24.381 quilogramas de produtos frutícolas e, em menores volumes, os aeroportos de Rio de Janeiro e Campinas concentraram 9.828 e 8.736 quilogramas de produtos com destino ao mercado externo. 4

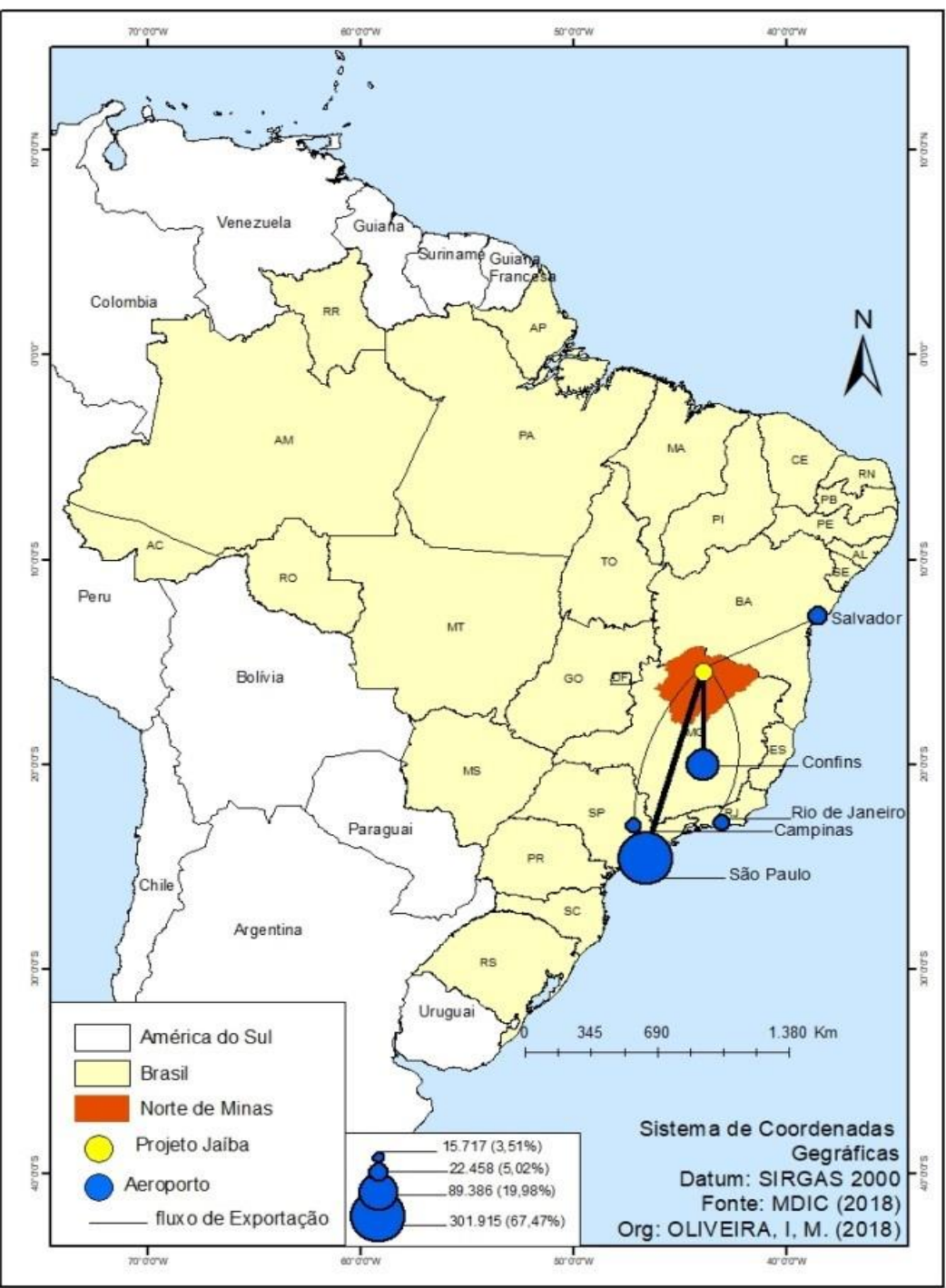

Figura 7 - Exportações no Projeto Jaíba: Localização dos Recintos Alfandegados aeroportuários e fluxos acumulados no período de 2000 a 2017 (US\$/FOB). Fonte: MDIC, 2018. Org. Oliveira, 2018. 


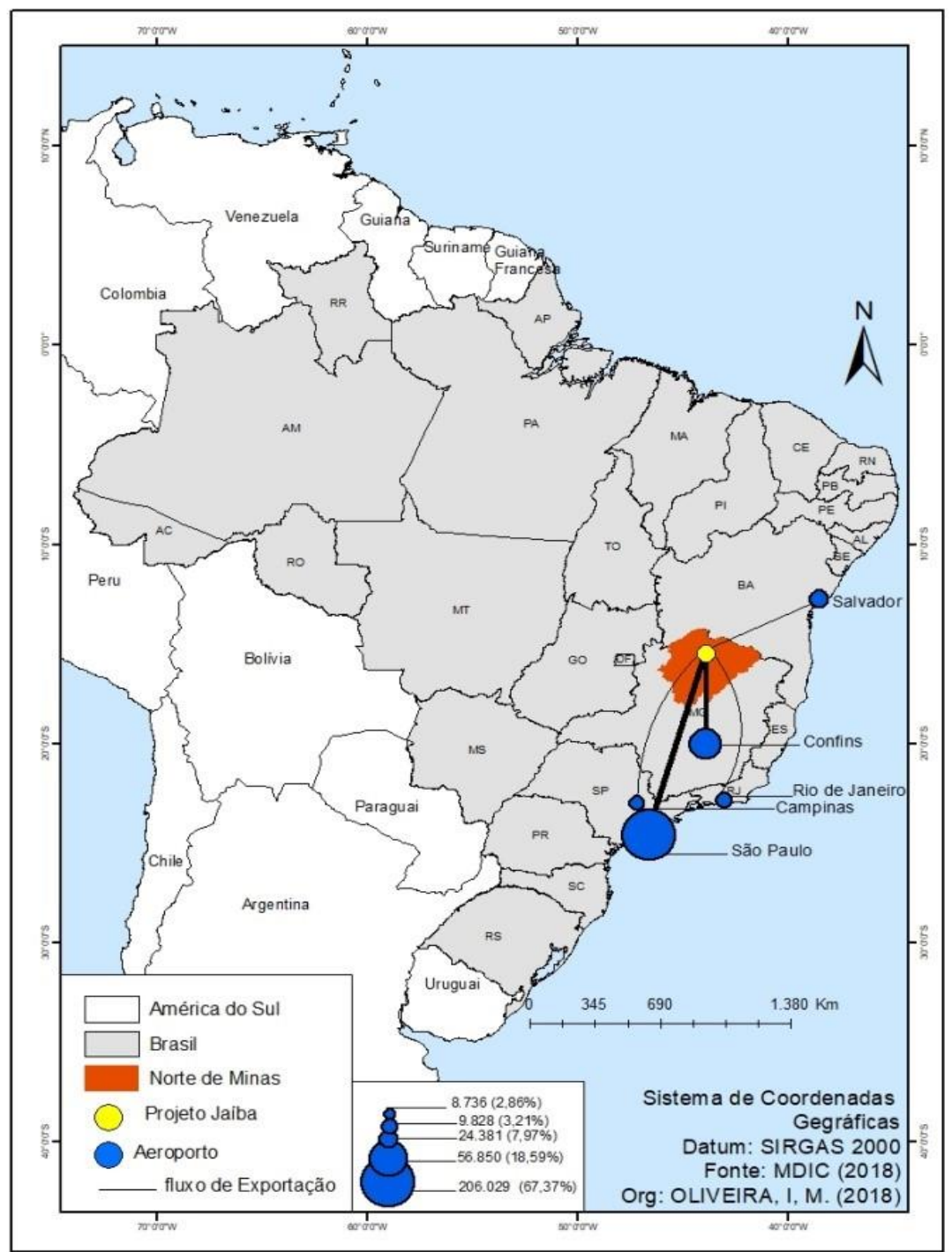

Figura 8 - Exportações no Projeto Jaíba: Localização dos Recintos Alfandegados aeroportuários e fluxos acumulados no período de 2000 a 2017 (Kg). Fonte: MDIC, 2018. Org. Oliveira, 2018.

A reorganização mundial dos espaços produtivos incluíram um conjunto de transformações espaciais e comerciais, criando, nos portos e nas regiões portuárias, novos métodos de movimentação de cargas, equipamentos sofisticados, implementação tecnológica e utilização de mão de obra especializada. A importância logística dos portos no processo de circulação os torna não apenas um corredor, nó logístico, mas um instrumento a serviço de um projeto de desenvolvimento (MONIÉ, 2003; MONIÉ E VIDAL, 2006).

A via marítima foi utilizada para transportar o maior fluxo $(98,49 \%)$ de produtos oriundos da região do Jaíba. Além dos recintos localizados nos aeroportos, sete portos foram utilizados na constituição da rede de transporte, tendo como destino 24 países como demonstrado na Tabela 3.

Entre os anos de 2000 a 2017, foram transportados pela via marítima 20 milhões de quilogramas de produtos oriundos da fruticultura, mantendo relação direta com cinco estados diferentes por meio de seus links logísticos. Ao analisar os principais destinos, os Países Baixos receberam o maior volume de produtos transportados por essa via de transporte; é importante destacar 
a importância logística desempenhada pelo Porto de Roterdã, localizado naquele país. Roterdã é o principal porto da Europa, sendo responsável pela distribuição de grande parte dos produtos nos mercados europeus.

Verifica-se, por meio da Figura 9, que, aproximadamente, 98\% do fluxo comercializado pelas empresas localizadas na região produtiva do Jaíba se concentrou em apenas dois portos. O maior fluxo de mercadorias (12,1 milhões de quilogramas) foi exportado a partir do porto de Salvador, localizado no estado da Bahia, representando 64,9\% do total comercializado. Do Porto do Santos $\mathrm{SP}$, foi enviado o segundo maior fluxo de produtos para o mercado externo, 6.289.832 quilogramas $(33,7 \%)$. Aproximadamente $1,5 \%$ dos produtos exportados tiveram como recintos alfandegados os portos de Parnamirim (RN), 146.286 (0,8\%), de Fortaleza (CE), 58.464 (0,31\%), de Pecém (CE), 48.861 (0,26\%), e o porto do Rio de Janeiro, que emitiu o menor fluxo, 10.580 quilogramas, ou seja, $0,1 \%$ do total comercializado. A concentração do fluxo no porto de Salvador se deu, notadamente, por sua proximidade com a região produtiva do Jaíba, tendo em vista que, custo e distância estão diretamente relacionadas na estratégia logística. A concentração do fluxo monetário (Figura 10) obedeceu à mesma ordem do fluxo em quilogramas.

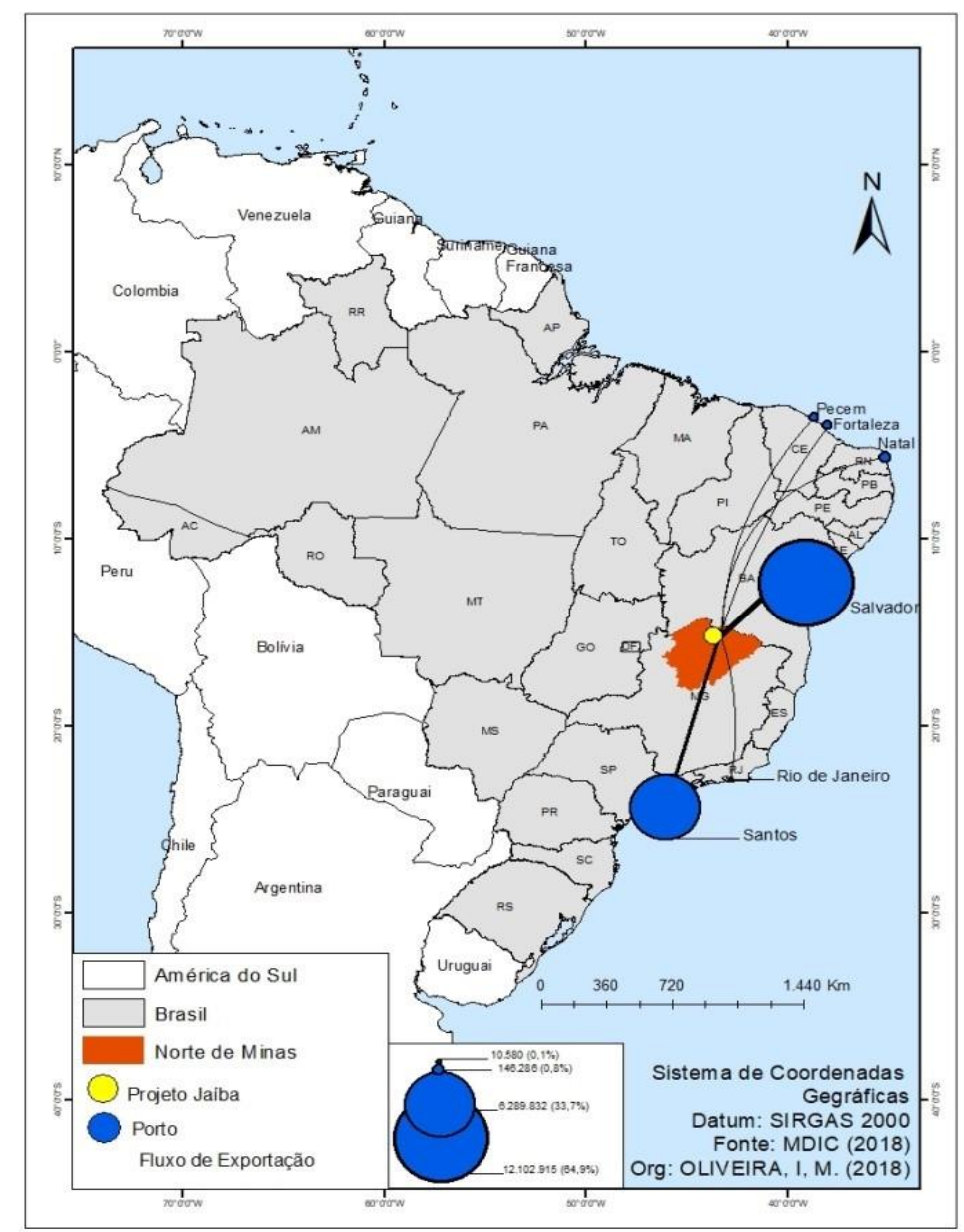

Figura 9- Exportações no Projeto Jaíba: Localização dos Recintos Alfandegados portuários e fluxos acumulados no período de 2000 a 2017 (Kg) Fonte: MDIC, 2018. Org. Oliveira, 2018. 
É importante destacar, ainda, que o processo de exportação de produtos para os países da América do Sul que fazem fronteiras com o Brasil, como é o caso do Uruguai e Colômbia, os quais, embora ligados por rodovias, utilizaram a via marítima no processo de importação de mercadorias; entre outros motivos, pode-se indicar o custo do transporte como o principal fator de escolha. Assim, pode-se inferir que além do fator distância a escolha do tipo de transporte utilizado pode variar de acordo com disponibilidade de mão de obra especializada, condições de acessos, infraestrutura disponíveis, entre outros. Todos esses fatores resultam na importância da operacionalização da logística como condição necessária para o dinamismo e expansão do setor.

É necessário destacar, ainda, a importância do transporte terrestre para a operacionalização da logística aplicada à fruticultura da Região Produtiva do Jaíba, tal como ocorre no restante do país. A literatura especializada tem, com frequência, criticado o sistema de transportes brasileiro quanto à qualidade da infraestrutura, ao alto custo do serviço e à concentração do modal rodoviário que responde por, aproximadamente, 65\% do fluxo do país (SOUZA; SILVEIRA, 2011). Embora muito criticado, esse tipo de transporte favorece a especialização produtiva dos lugares por apresentar flexibilidade em transportar diferentes tipos de cargas, completas ou fracionadas, bem como pela sua cobertura territorial que atinge pontos remotos do país, em que outros tipos de modais não poderiam chegar devido à inexistência de redes de infraestrutura.

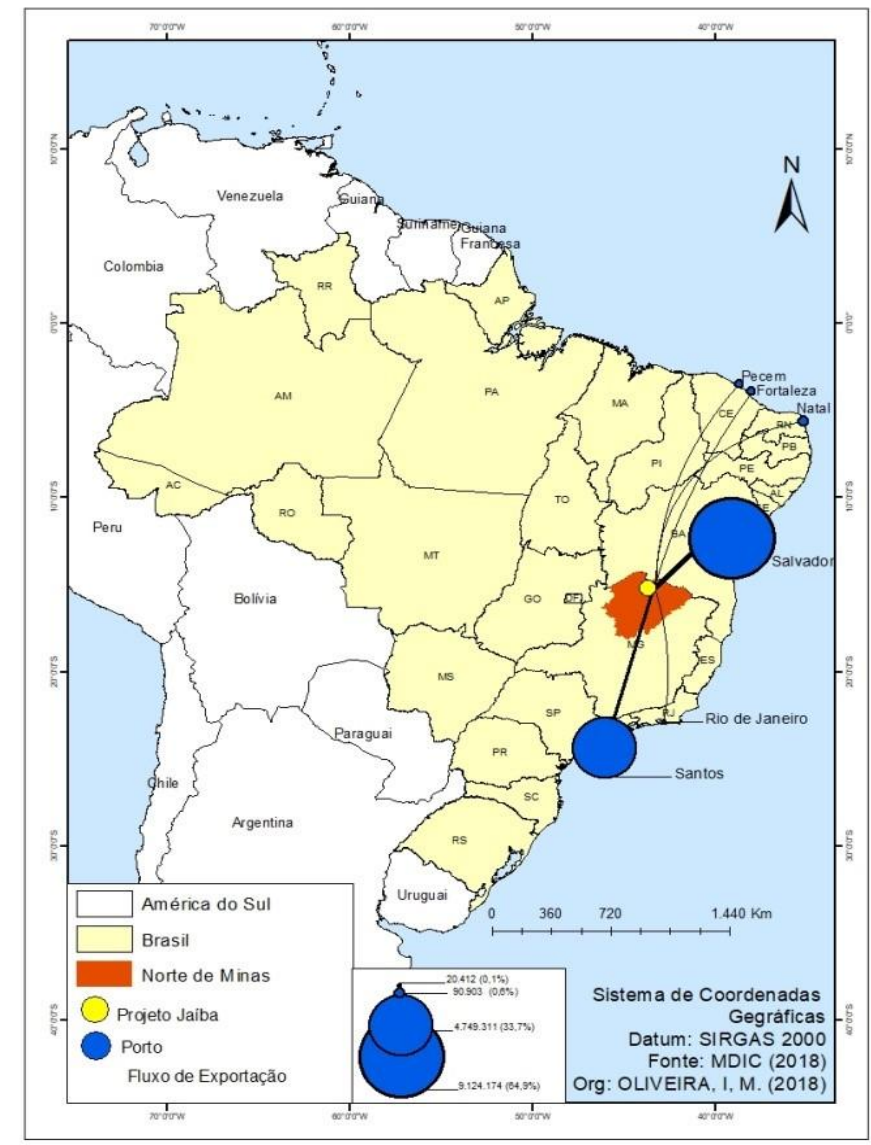

Figura 10 - Exportações no Projeto Jaíba: Localização dos Recintos Alfandegados portuários e fluxos acumulados no período de 2000 a 2017 (US\$/FOB). Fonte: MDIC, 2018. Org. Oliveira, 2018. 
Borgo (2013) propõe o entendimento da totalidade das redes de transportes ao considerar que as infraestruturas individualizadas não têm alguma função no complexo mundo dos transportes, em que tudo funciona "em rede", ou seja, assumindo que cada nó tem um papel determinado dentro de uma hierarquia vertical e horizontal. A visão da totalidade do processo é de fundamental relevância para a eficiência do gerenciamento da cadeia de suprimentos da fruticultura, minimizando ao máximo as perdas de produtividade.

No caso do transporte de frutas, a utilização de transporte refrigerado é o mais indicado, contudo, esse tipo de veículo agrega maior investimento do produtor. Operar com produtos/equipamentos inadequados ou obsoletos pode comprometer todo o carregamento, e assim, reduzir a competitividade em termos de qualidade, velocidade e custo (LOURENÇO; KATZ, 2010). Os autores consideram ainda que, no Brasil, o mercado de produtos refrigerados tem encontrado dificuldades na padronização das embalagens de cada produto.

Finalizada a análise da rede de exportação de frutas realizada pela região do Jaíba, na próxima seção deste trabalho analisou-se a logística interna das empresas exportadoras da região em estudo.

\section{AS EMPRESAS EXPORTADORAS DA REGIÃO PRODUTIVA DO JAÍBA: BREVES CONSIDERAÇÕES ACERCA DA LOGÍSTICA DA FRUTICULTURA}

No processo de exportação dos produtos oriundos da região produtiva do Jaíba, foram identificadas seis empresas que participaram, em algum momento, do comércio internacional e que estão vinculadas ao CNAE: cultivo de frutas de lavoura permanente, exceto laranja e uva, comércio atacadista de hortifrutigranjeiros e fabricação de sucos de frutas, hortaliças e legumes. Do total de empresas exportadoras presentes na região, apenas a metade delas concordaram participar desta pesquisa.

Por meio dos trabalhos de campo, bem como das entrevistas e conversas com os representantes das empresas que atuam no mercado externo da região do Jaíba, foi possível compreender mais profundamente a logística utilizada pelas empresas exportadoras, sobretudo, nos processos realizados nas Packing Hauses. Para manter o sigilo das empresas, optou-se pelo emprego de nomes fictícios. De início, podem-se identificar as seguintes proposições acerca das empresas exportadoras do Jaíba:

- $\quad$ atuam no mesmo mercado: Europa e Ásia, principalmente;

- $\quad$ trabalham com o mesmo tipo de produto: o limão tipo Tahiti;

- trabalham em parceria com uma rede de associação/cooperativa e trading company;

- $\quad$ trabalham com uma mesma média de custo de transporte;

- utilizam, em regra, os mesmos recintos alfandegados;

- $\quad$ possuem o mesmo concorrente externo: O México. 
A empresa A, que possui escritório na área urbana da cidade de Jaíba, trabalha no modelo de trading, ou seja, compra o produto para vendê-lo no mercado externo. Além dos parceiros fornecedores da região do Jaíba, a empresa compra limão de produtores do estado de São Paulo, Sergipe e Bahia. Segundo sua representante, somente os frutos dos agricultores certificados são adquiridos, e esses passam por diferentes e rigorosos sistemas de classificação quanto à qualidade, aparência física e ao calibre (tamanho) do fruto, por serem essas as principais exigências dos compradores externos, para ela, esse padrão de controle deve ser seguido para garantir a qualidade e as características exigidas pelos importadores. O processo de seleção dos limões está representado pela Figura 11.

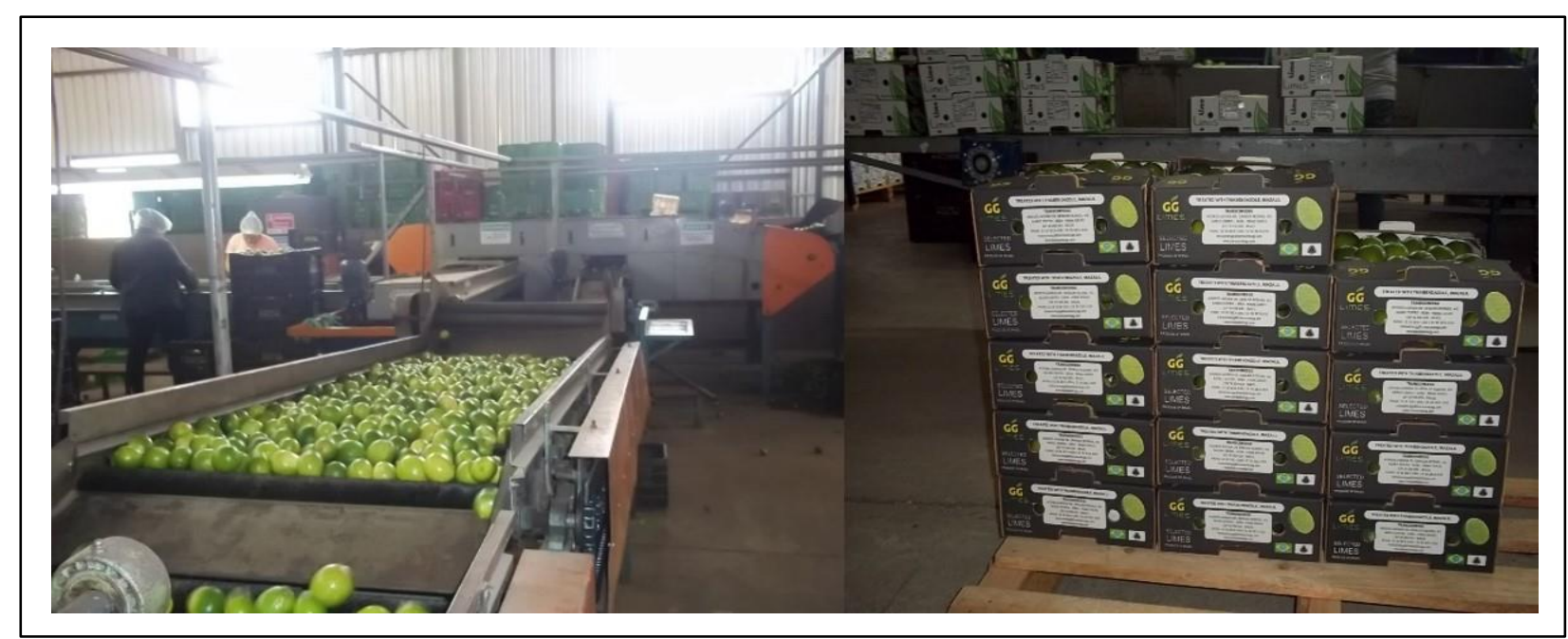

Figura 11 - Mosaico: Etapas de classificação e empacotamento do limão. Fonte: Oliveira, 2018.

No mercado externo, a empresa A exporta seus produtos para os países do Oriente Médio, com destaque para os Emirados Árabes Unidos e Arábia Saudita; e para a Europa, cujos maiores fluxos são para a Holanda, Inglaterra e Bélgica. A empresa possui frota própria, formada por três caminhões refrigerados.

Para a realização da etapa logística concernente ao transporte, três tipos de modais são utilizados pela empresa A: o rodoviário, o aeroviário e o marítimo. Embora seja o mais eficiente, quanto à agilidade (tempo) e manutenção dos frutos, o transporte aéreo é pouco utilizado pela empresa devido aos custos logísticos desse modal, (segundo a empresa para transportar os limões para a Europa são necessários de oito a doze horas). Os recintos alfandegados utilizados pela empresa A, ao utilizar o modal aéreo, foram os aeroportos de São Paulo, Confins e Rio de Janeiro.

O modal marítimo se destaca como a principal via utilizada pela empresa A nas exportações. Esse modal destaca-se pelo seu baixo custo operacional e pela capacidade de transportar grandes quantidades de mercadorias. A empresa A comercializa, em média, por esse modal, de dois a três 
contêineres contendo 5400 caixas de limão por semana ${ }^{8}$. Em 2016, por exemplo, foram exportados, aproximadamente, 140 contêineres de limão, em 2018, registrou-se queda na produção regional e nas exportações, foram 118 contêineres comercializados no mercado externo, redução de 15,71\%.

De acordo com o acompanhamento de fluxo da empresa A, os navios com os carregamentos de limão gastam entre 13 a 17 dias para chegar ao mercado europeu, e de 29 a 38 dias para chegar ao Oriente Médio. Os recintos alfandegados utilizados para o transporte marítimo foram: os portos de Salvador, Santos e Rio de Janeiro; a preferência da empresa é escoar o fluxo por Salvador por esse ser mais próximo da Europa, bem como da região produtiva, o que agiliza as etapas logísticas reduzindo desta forma tempo e custo. A depender da demanda, a empresa utiliza também os portos de Pecém e Natal, localizados no estado do Rio Grande do Norte. Todo o transporte até os recintos alfandegados é realizado pela própria empresa, utilizando a via rodoviária.

Para a empresa A, por administrar seus processos logísticos, a região do Jaíba possui a infraestrutura necessária para o desenvolvimento do setor, contudo, aponta que o estado das estradas do projeto dificulta o fluxo dos caminhões, sobretudo, no período da safra, quando outras empresas aumentam seu contingente de veículos. Sobre os custos, o maior investimento necessário é voltado para a manutenção dos veículos, devido à precariedade das rodovias do país. No mercado externo, a empresa possui um representante responsável pelo contato direto com os clientes.

Essa visão positiva quanto à infraestrutura da região não é compartilhada por todas as empresas, durante a pesquisa foi possível identificar que uma delas, a empresa B, realiza parte de suas etapas logísticas em sua sede no estado de São Paulo. Para essa empresa, as deficiências da infraestrutura da região do Jaíba impossibilitam a realização das etapas finais do processo logístico.

Também a localização do projeto de irrigação distante dos grandes centros dificulta o acesso a serviços especializados. Isso demonstra a importância do sistema técnico para o desenvolvimento do setor frutícola na região. A descentralização dos processos para outras regiões e estados pode significar menor receita aplicada/investida na região, além da diminuição nos postos de trabalho.

A terceira empresa entrevista foi denominada de empresa $\mathrm{C}$, que possui escritório na área urbana da cidade de Jaíba, contudo, sua Packing House localiza-se no município de Matias Cardoso, isso demonstra a relação contínua entre os municípios do projeto, o que fortalece uma das teses inicial desse trabalho: a formação da região produtiva do Jaíba. A empresa C funciona em formato de associação e brevemente se tornará uma cooperativa ${ }^{9}$. Segundo a representante do empreendimento, seus agricultores foram os precursores do cultivo de limão na região do Jaíba, tendo, desde a primeira safra, o objetivo de inserção no mercado externo. Para atingir tal objetivo, uma série de providências foram tomadas, tais como montagem de estrutura, contratação de consultor de mercado, contratação

\footnotetext{
${ }^{8}$ Durante o período de safra.

${ }^{9}$ Informação da Própria empresa.
} 
de mão de obra qualificada no estado de São Paulo, grande produtor de citros e concorrente direto da empresa $\mathrm{C}$ no mercado interno, para o treinamento dos profissionais que atuam na packing house.

Atualmente, a empresa $\mathrm{C}$ possui 10 sócios (produtores) e trabalha com limão, manga e maracujá, com capacidade de exportar um contêiner de limão por dia. Além desse volume que é exportado, a empresa trabalha ainda como fornecedor de limão para quatro tradings, sendo duas do estado de São Paulo, uma da cidade de Petrolina e uma da cidade de Jaíba (Empresa A). Para a empresa C, a grande vantagem no comércio com as tradings é a economia com as etapas logísticas, sobretudo, o transporte. Sobre a concorrência externa, a empresa aponta o México como um grande produtor de limão tipos Tahiti e Siciliano. No mercado externo, a empresa possui um representante responsável pelo contato direto com os clientes.

Segundo um de seus representantes, desde o ano de 2013, os limões produzidos na região do Jaíba são exportados para países do Oriente Médio como Emirados Árabes Unidos, Catar, Bahrein, Arábia Saudita e Omã (CÂMARA DE COMÉRCIO ÁRABE-BRASILEIRA, 2016). Para ele, em 2015, a associação vendeu 10.366 toneladas de limão, dos quais 35\% foram exportados (em entrevista concedida ao jornal "Estado de Minas" em 2016, a empresa C apontou que 40\% de sua produção era destinada ao mercado externo). Do total embarcado para o exterior, cerca de $12 \%$ foi para países árabes (ESTADO DE MINAS, 2016).

Ao se comparar esses dados vinculados com aqueles da estatística oficial do MDIC, referentes aos produtos agrupados no SH 0805 (Citrinos, frescos ou secos), percebe-se que o valor exportado, conforme foi informado pela empresa C (3.628.100 de quilogramas), foi superior ao disposto no AliceWeb2 para o ano de 2015 que foi de 3.385.016 quilogramas exportados (esse total corresponde a duas empresas que exportaram limão naquele ano); isso pode significar a existência de um fluxo de exportação indireta dos produtos citrícolas do Jaíba.

Sobre a importação indireta, deve-se ressaltar que essa é uma prática juridicamente legal e reconhecida pelo MDIC que a conceitua como "quando a operação do processo de exportação é executada por um interveniente, geralmente uma empresa de exportação" (AGENCIA DE NOTÍCIAS BRASIL - ÁRABE - ANBA, 2016; MDIC, 2018, s/p).

Dentro da macroestrutura do agronegócio, as importações indiretas (geralmente praticadas pelas trading companies) apresentam vantagens, principalmente, para os pequenos e médios produtores que não possuem estrutura própria dedicada ao comércio internacional (MDIC, 2012). É importante destacar que, com a exportação indireta, o produtor fica fora de parte do processo de comercialização, como conhecimento do mercado externo, características e preços praticados e privação de eventuais ganhos financeiros (COSTA et al., 2014).

Relacionando a exportação indireta ao objeto de estudo deste trabalho, pode-se pensar em exportação indireta entre os municípios, por exemplo, muitos dos produtos exportados por Jaíba são 
cultivados em Matias Cardoso, ou seja, mesmo não contabilizando nas estatísticas oficiais, esse município participa indiretamente do processo de exportação. Isso é uma prática comum em regiões produtivas formadas por mais de um município.

Estruturalmente, a empresa $\mathrm{C}$ apresenta uma considerável estrutura formada por área de recebimento, seleção, qualidade, empacotamento e armazenamento, como demonstrado na Figura 12. Todas as etapas logísticas intra Packing House são monitoradas também por câmeras.

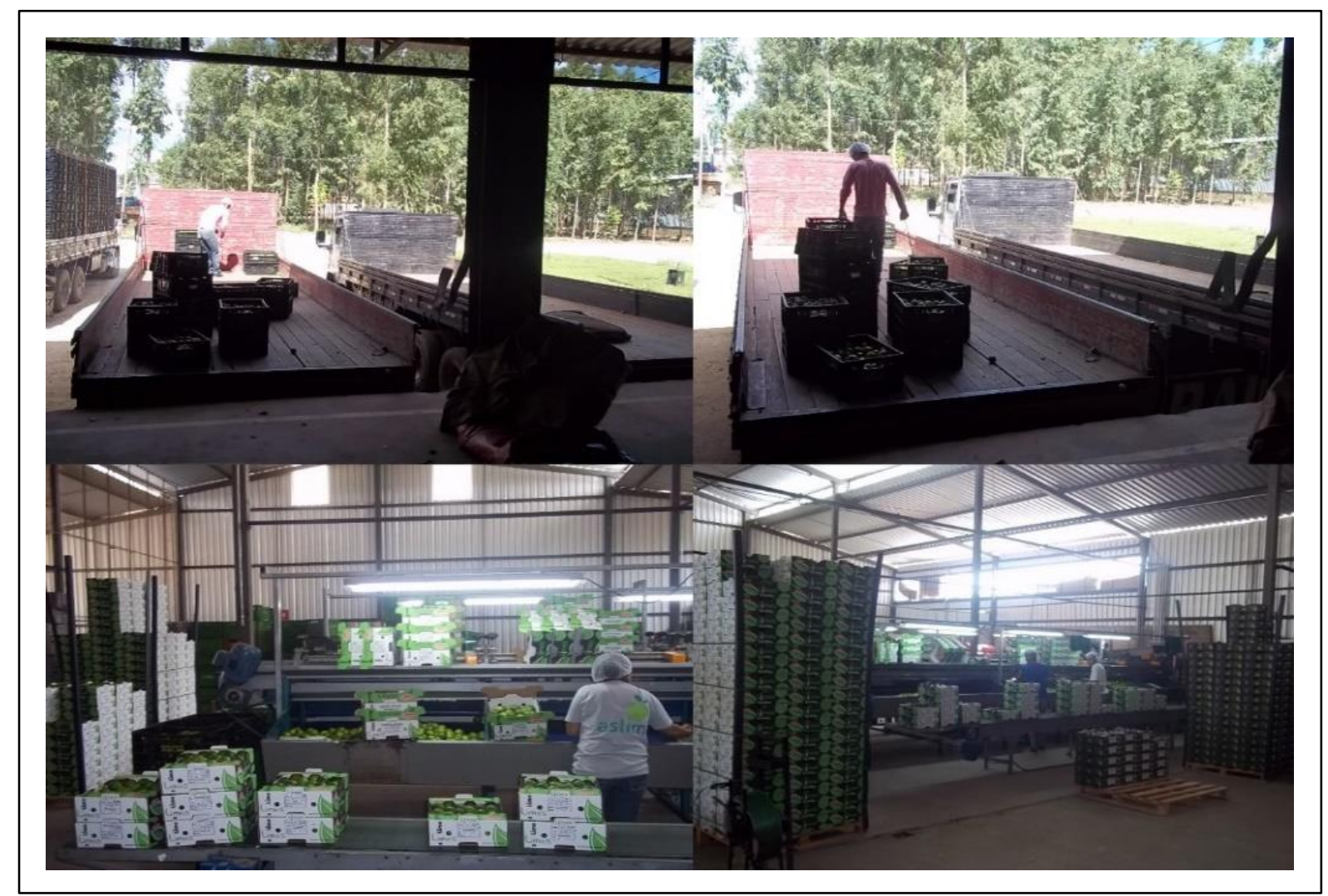

Figura 12 - Mosaico Empresa C - Etapas logística intra Packing House: Recebimento/transporte, seleção e empacotamento

Fonte: Oliveira, 2018.

Todo o contingente de produto é aproveitado pela empresa C; não se identificaram perdas nas etapas logísticas, na seguinte escala: o limão de excelência é destinado ao mercado externo; em seguida, (segundo lote) é destinado ao mercado interno nacional e os demais são direcionados para os mercados regional e local. O calibre do limão também determina o modal de transporte a ser utilizado pela empresa. Os limões maiores são transportados por via aérea, o que corresponde a 10\% do fluxo da empresa. Já os $90 \%$ restantes correspondem aos frutos menores, esses são transportados por via marítima, utilizando, principalmente, o porto de Salvador. O calibre do limão influencia também em sua "vida útil", conforme explicação da empresa, a "vida" do limão de maior calibre é menor quando comparado ao limão pequeno. 
O carregamento por Salvador demora, em média, 30 dias para chegar ao mercado árabe (porto de Dubai, Emirados Árabes). Há, também, o fluxo de transporte com destino à Europa, nesse fluxo é utilizado também o Porto de Santos com destino ao Porto de Roterdã, Holanda. É importante destacar a utilização do modal rodoviário pelo qual é transportada a mercadoria do galpão do projeto de irrigação (Packing House) até os recintos alfandegados (AGÊNCIA DE NOTÍCIAS BRASIL ÁRABE), 2016; ESTADO DE MINAS, 2016).

No que concerne aos custos do transporte, segundo um representante da empresa $\mathrm{C}$, o custo de transporte de um contêiner de 40 (pés), carga refrigerada (comprimento 12,192 / larg.: 2,438 / alt.: 2,590) da região do Jaíba até os portos de Salvador e/ou Santos é de, aproximadamente, R \$ 6.500,00, variando até R \$ 7.200, 00. Já para os portos de Pecém e Natal, custa em média R \$ 10.200,00. Desses portos até os portos da Inglaterra e/ou Holanda, tem-se um custo de, aproximadamente, US\$ 2.500. No comércio internacional, a distância e o tipo de modal utilizado não são os únicos condicionantes do preço; o agente econômico que atua nesse mercado deve-se atentar também para fatores como: horário, rota, frequência e quantidade de mercadoria a ser transportada, principalmente.

Quando questionada sobre as dificuldades logísticas nas exportações, a empresa C aponta que o maior gargalo do setor está nas barreiras fitossanitárias, impostas pelos países importadores. Também os entraves burocráticos/institucionais, tal como a quantidade de autorizações, de licenças e de documentos exigidos dificulta o processo de exportações.

Para a realização do transporte internacional, as empresas firmam contratos com importantes empresas do mercado de logística internacional como a Maersk, empresa com sede em Copenhague, Dinamarca, a alemã Aliança/Hamburg Süd, a Mediterranean Shipping Company - MSC, cuja sede se localiza em Genebra, Suíça e a também alemã Lufthansa cargo.

\section{CONSIDERAÇÕES FINAIS}

No transcorrer deste trabalho, buscou-se compreender a logística aplicada ao setor de fruticultura da região produtiva do Jaíba por meio das redes de exportações mercadorias. A escolha do espaço amostral da pesquisa não foi por acaso, mas partiu da pretensão de aprofundar o conhecimento da Geografia do Norte de Minas por toda a sua singularidade na perspectiva da especialização produtiva do território. Para tanto, foi necessário tecer relações teóricas que contribuíssem para esse objetivo.

Com a globalização, a economia mundial passa por uma reestruturação produtiva, intensificando nos territórios os processos inerentes à competição para a captação de bens, recursos, mercados e especialidades. Por meio do contexto de especialização produtiva que o Projeto Jaíba se 
inseriu no mercado externo de produtos frutícolas, com destaque para o limão e para a manga, principais produtos da cesta de exportação da Região Produtiva.

Pode-se inferir, a partir deste estudo, que a ascensão de regiões produtivas como a do Jaíba, especializadas na fruticultura irrigada, está diretamente relacionada à aplicação da ciência, da técnica, da informação e da circulação. Nessa perspectiva, concorda-se com o pensamento de Castells (1999, p. 411), ao analisar a existência dos lugares a partir da perspectiva das redes, quando afirma que "nenhum lugar pode existir em si mesmo, uma vez que os lugares são definidos pelos fluxos", bem como com Santos (2006) ao considerar que nas configuração do sistema econômico atual, não basta apenas produzir a mercadoria, é indispensável que essa seja colocada em circulação. Dessa forma, pode-se afirmar que não é mais a produção que preside à circulação, mas é essa que controla e dinamiza a produção.

A região do Norte de Minas está localizada em uma zona secundária do território brasileiro, não apresentando nenhum recinto alfandegado. Por isso, as empresas da região que participam do comércio internacional necessitam utilizar os serviços aduaneiros de outras regiões, principalmente, os portuários e os aeroportuários. Assim, para sua inserção nas redes de comércio globais, a região produtiva do Jaíba necessita de uma rede de infraestrutura composta por estradas locais, rodovias estaduais, federais, portos e aeroportos.

O espaço geográfico, articulado por redes de infraestrutura e de serviços de fluxos materiais (mercadorias) e imateriais (serviços e informações), tem ampliado a participação das regiões produtivas no comércio internacional, contribuindo, diretamente, para a especialização espacial produtiva, tal como se tem desenvolvido na região do Jaíba.

No cenário do comércio global, a logística compreendida como o estágio atual do processo de circulação configura-se como um elemento geográfico, uma ferramenta indispensável para o comércio, para a fluidez e para a gestão dos territórios produtivos, principalmente, no Brasil, cuja matriz de transporte se concentra no modal rodoviário, diferentemente de países desenvolvidos de dimensões territoriais semelhantes.

Com esse estudo foi possível identificar o potencial da região do Jaíba na produção de frutas; as diversidades climáticas e a abundância de terras para o cultivo são algumas delas. Também se deve destacar a influência do desenvolvimento técnico científico no setor, a exemplo disso, podem-se apontar o desenvolvimento biológico de mudas e sementes, as tentativas de expansão de mercado por meio do desenvolvimento da estrutura logística e a modificação do espaço geográfico para a formação de complexo produtivo da fruticultura irrigada. Em contrapartida, a literatura especializada apresenta uma série de fatores que entravam/dificultam a inserção e/ou expansão do mercado brasileiro nas redes globais da fruticultura. Nesse cenário, as regiões produtivas voltadas para a fruticultura se 
diferenciam pelas adaptações do território, ou seja, da carga de maior ou de menor intensidade dos aparatos científicos, técnicos e informacionais (SANTOS, 2008).

Embora o município de Jaíba tenha se sobressaído devido a maior concentração de empresas exportadoras e de fluxos de comércio, percebeu-se ao longo deste trabalho, sobretudo, na etapa de pesquisa de campo que o local de registro das empresas não restringe sua área de atuação, por isso, ao longo deste trabalho, optou-se pela utilização do termo região produtiva do Jaíba, entendendo que a economia, a organização espacial, a prestação de serviços e a divisão do trabalho estão diretamente relacionadas ao Projeto de irrigação.

Internamente, o projeto apresenta uma considerável rede de estradas, canais de irrigação e de distribuição. Notou-se também que, embora fazendo parte do mesmo complexo, há uma visível concentração de atributos (infraestrutura, serviços), bem como da produção (área destinada à produção) no território do município de Jaíba (durante a pesquisa, identificou-se apenas uma empresa exportadora que possui sua Packing House no município de Matias Cardoso), o que contribui para a concentração das empresas e dos fluxos nesse município.

$\mathrm{Na}$ região produtiva do Jaíba, percebe-se um peso maior para as questões logísticas referentes à infraestrutura e à localização. Identificou-se, durante a pesquisa, uma empresa que transfere parte de suas etapas logísticas (produção/beneficiamento/armazenamento e comercialização) para o estado de São Paulo; para ela, a falta de infraestrutura da região e a longa distância dos principais portos do país dificultam a fluidez e agilidade que o mercado exige.

Pela complexidade do tema e de todos os processos envolvidos, alguns processos citados ao longo deste trabalho não foram ou não puderam ser aprofundados, todavia, esses poderão ser norteadores de novas pesquisas e reflexões, tais como o acesso do circuito inferior da economia frutícola ao mercado externo; a rede de exportação indireta da região; a atuação dos agentes atravessadores na região constituindo as redes comunicação e comércio; a logística intrarrecinto alfandegado (para as exportações e importação); as redes de integração e comunicação intraprojetos da região.

Pensar alternativas para maximizar os fluxos de comércio da região do Jaíba, requer pensar a logística não apenas como uma técnica gerencial/empresarial de controle de processos, mas como uma ferramenta de gestão territorial. A Geografia apresenta-se como importante aliada ao discutir a organização espacial e sua rede de transportes, circulação e comunicação. Por fim, espera-se que este estudo possa contribuir para o desenvolvimento da ciência geográfica, no tocando às análises, às políticas e à interpretação do desenvolvimento regional, sobretudo, do Norte de Minas. 


\section{AGRADECIMENTOS}

Agradecemos à Coordenação de Aperfeiçoamento de Pessoal de Nível Superior - CAPES, pela concessão de bolsa de mestrado. À Fundação de Apoio à Pesquisa do Estado de Minas Gerais FAPEMIG, pelo financiamento do projeto, ao qual encontra-se vinculada esta pesquisa.

\section{REFERÊNCIAS}

AGENCIA DE NOTÍCIAS BRASIL - ÁRABE - ANBA. Limões de Minas para o Oriente Médio. 23 de agosto de 2016. Disponível em: <httpss://www.ccab.org.br/pt/noticias/limoes-de-minas-parao-oriente-medio>. Acesso em: 19 jun. 2018.

ARROYO, M. Território nacional e mercado externo. Uma leitura do Brasil na virada do século XX. 2001. Tese (Doutorado em Geografia) - Faculdade de Filosofia, Letras e Ciências Humanas, Universidade de São Paulo, São Paulo, 2001.

BARAT, J. A Evolução dos Transportes no Brasil. 1. ed. Rio de Janeiro: IBGE/IPEA, 1978, 391p.

BLANCO, J. Territorio, circulación y Redes: Articulaciones y Tensiones. In: ARROYO, M.; CRUZ, R. C. A. Território e Circulação: A Dinâmica Contraditória da Globalização (Org.). São Paulo: FAPESP/PPGH/CAPES/Annablume Geografias, 2015, p. 15-36.

BRAGA, V.; CASTILLO, R. Tipologia e topologia de nós logísticos no território brasileiro: uma análise dos terminais ferroviários e das plataformas multimodais. Boletim Campineiro de Geografia, v. 3, n. 2, p. 235-258, 2013.

BRASIL, Ministério de Relações Exteriores - Departamento de Promoção Comercial e Investimentos. Como Exportar: União Europeia, 2012. 103p.

BURGOS, F. J. A. Rede de transporte, articulación territorial y desarrollo regional. Revista de Estudios Andaluces, n. 30, p. 27-47, 2013.

CASTILlO, R.; ELIAS, D.; PEIXINHO, D.; BUHLER, E. A.; PEQUENO, R.; FREDERICO, S. Regiões do Agronegócio, Novas Relações Campo-Cidade e Reestruturação Urbana. Revista da Associação Nacional de Pós-graduação e Pesquisa em Geografia, v. 12, n. 18, p. 265-288, 2016.

DAVID, P.; STEWART, R. Logística internacional. Tradução de Laís Andrade. São Paulo: Cengage Learning, 2010. 416p.

DIJ - Distrito de Irrigação de Jaíba. Projeto Jaíba. Disponível em: <https://www.projetojaiba.com.br/index.php/>. Acesso em: 07 jan. 2017.

DUARTE, S. V.; TAVARES, M. C. Sistema de Distribuição de Produtos Agrícolas: Facilidades e Dificuldades do Escoamento da Produção: Um Estudo de Caso do Projeto Jaíba. Unimontes Científica. Montes Claros, v. 2, n. 2, p. 01-25, 2001.

ESTADO DE MINAS. Limão do Projeto Jaíba conquista o mundo. 22 de agosto de 2016. Disponível em: <https://aconteceunovale.com.br/portal/?p=95468>. Acesso em: 19 jun. 2018.

FONSECA, A. I. A.; ROSÁRIO, G. A.; ALMEIDA, L. D. S.; FERREIRA, L. G. Configuração da Agricultura Familiar no Projeto Jaíba em Cinquenta Anos de Existência. Revista Geográfica de América Central, v. 2, n. 47, p. 1-13, 2011. 
IBGE. Instituto Brasileiro de Geografia e Estatística. Produção Agropecuária Municipal: Jaíba. Disponível em: https://sidra.ibge.gov.br/tabela/5457. Acesso em: 17 fev. 2018.

Produção Agropecuária Municipal: Matias Cardoso. Disponível em: https://sidra.ibge.gov.br/tabela/5457. Acesso em: 17 fev. $2018 .$.

LOURENÇO, J. O.; KATZ, I. Estudos dos Diversos Índices de Perdas no Manuseio e Transporte de Verduras, Legumes e Frutas Relacionadas à Gestão Logística. Tékhne $\boldsymbol{\varepsilon}$ Lógos, Botucatu, v. 2, n, 1, p. 110-125, 2010.

MARTINS, R. S.; CAIXETA FILHO, J. V. O Desenvolvimento dos Sistemas de Transporte: Auge, Abandono e Reativação Recente das ferrovias. Teor. Evid. Econ, Passo Fundo, v. 6. n. 11, p. 69-91, 1998.

MARTINS, S.; SILVEIRA, S. F. R.; GOMES, R. C.; ADAMI, T. H. O Processo de Implementação do Projeto Jaíba na Percepção de Atores Políticos e Burocratas. In. ENCONTRO DA ANPAD. 32., , 2008. Rio de Janeiro. Anais... Rio de Janeiro: ANPAD, 2008. p. 1-16.

MARTINS, S. Análise da Implementação da Política Nacional de Irrigação no Norte de Minas Gerais: o caso do Projeto Jaíba. 2008. 215 f. Dissertação (Mestrado em Administração) - Programa de Pós-Graduação em Administração, Universidade Federal de Viçosa. Viçosa, 2008.

MINISTÉRIO DA INDÚSTRIA, COMÉRCIO EXTERIOR E SERVIÇOS - MDIC. Empresas brasileiras exportadoras e importadoras. Disponível em: https://www.mdic.gov.br/comercioexterior/estatisticas-de-comercioexterior/empresas-brasileiras-exportadoras-e-importadoras. Acesso em: 27 abr. 2018.

- INTERNACIONALIZAÇÃO EXPORTAÇÃO DIRETA E INDIRETA, 2012. Disponível em: https://www.mdic.gov.br/sistemas_web/aprendex/cooperativismo/index/conteudo. Acesso em: 25 jun. 2018.

MINISTÉRIO DO DESENVOLVIMENTO INDÚSTRIA E COMÉRCIO EXTERIOR. Exportação municípios (Jaíba) 2000 - 2017. Disponível em: https://aliceweb.mdic.gov.br. Acesso em: 03 ago. 2017.

- Exportação municípios (Matias Cardoso) 2000 - 2017. Disponível em: https://aliceweb.mdic.gov.br. Acesso em: 03 ago. 2017.

MONIÉ, F.; VIDAL, S. M. S. C. Cidades, portos e cidades portuárias na era da integração produtiva. RAP, Rio de Janeiro, v. 40, n. 6, p. 975-995, 2006.

PEREIRA, L. A. G.; FERREIRA, W. R. Comercialização, logística de transportes e exportações do setor de fruticultura no projeto Jaíba. GeoTextos, v. 12, n. 1, p. 183-206, 2016.

PEREIRA, A. M.; SOARES, B. R. Montes Claros e sua Região: Novas Espacialidades, Velhos Problemas. In: ENCONTRO DE GEÓGRAFOS DA AMÉRICA LATINA. 10., São Paulo. Anais... São Paulo: USP, 2005. p. 11609-11625.

RODRIGUES, L. Potencial da Agricultura Irrigada como Indutora do Desenvolvimento Regional: o caso do projeto Jaíba no Norte de Minas Gerais. Revista Econômica do Nordeste, Fortaleza, v. 32, n. 2, p. 2006-232, 2001. 
SANTOS, M. Técnica, espaço, tempo: globalização e meio técnico-científicoinformacional. São Paulo: Editora da Universidade de São Paulo, 2008. 176p.

SANTOS, M. A Natureza do Espaço: Técnica e Tempo. Razão e Emoção. 4. ed. São Paulo: Editora da Universidade de São Paulo, 2006. 388p.

SANTOS, Milton. Da Política do Estado à Política das Empresas: Globalização e Política. Cadernos da Escola do Legislativo, Belo Horizonte, v. 3, n. 6, p. 9-23, 1997.

Espaço e Método, São Paulo: Nobel, 1985. 120p.

SANTOS, G. R.; SILVA, R. S. Os Irrigantes do Projeto Jaíba: Da Produção de Subsistência à Agricultura Moderna. Cadernos do Desenvolvimento, v. 5, n. 7, p. 349-372, 2010.

SILVA, P. C. G. Articulação dos Interesses Públicos e Privados no Pólo Petrolina-PE/JuazeiroBA: Em Busca de Espaço no Mercado Globalizado de Frutas Frescas. 2001, 258 f. Tese (Doutorado em Economia Aplicada) - Universidade Estadual de Campinas, Campinas, 2001.

SILVEIRA, M. R. Circulação, Transportes, Logística e a Dinâmica Capitalista: Alguns apontamentos sobre as recentes reestruturações no Brasil. In: ARROYO, M.; CRUZ, R. C. A. Território e Circulação: A Dinâmica Contraditória da Globalização (Org.). São Paulo: FAPESP/PPGH/CAPES/Annablume Geografias, 2015. p. 51-73.

SOUZA, V. H. P.; SILVEIRA, M. R. O transporte rodoviário no Brasil: algumas tipologias da viscosidade. In: SILVEIRA, M. R. (Org.). Circulação, transportes e logística: diferentes perspectivas. São Paulo: Outras Expressões, 2011. p. 277-298. 